\title{
A Framework for a Subwatershed-Scale Screening Tool to Support Development of Resiliency Solutions and Flood Protection Priority Areas in a Low-Lying Coastal Community
}

\author{
Frederick Bloetscher, Gerardo Rojas, Anthony Abbate, Tucker Hindle, Jeffery Huber, \\ Richard Jones, Weibo Liu, Daniel Eduardo Meeroff, Diana Mitsova, Sudhagar Nagarajan, \\ Glen Oglesby, Colin Polsky, Hongbo Su, Eva Suarez, Ramesh Teegavarapu, Jared Weaver, \\ Zhixiao Xie, Yan Yong, Caiyun Zhang
}

Florida Atlantic University, Boca Raton, USA

Email: fbloetsc@fau.edu, grojas2017@fau.edu, aabbate@fau.edu, thindle2016@fau.edu, huberj@fau.edu, rjones99@fau.edu, liuw@fau.edu,dmeeroff@fau.edu,dmitsonva@fau.edu, snagarajan@fau.edu,goglesby2016@fau.edu,cpolsky@fau.edu, shu@fau.edu, ediazsu@fau.edu, rteegava@fau.edu, weaverj2014@fau.edu, xie@fau.edu, yongy@fau.edu, czhang3@fau.edu

How to cite this paper: Bloetscher, F., Rojas, G., Abbate, A., Hindle, T., Huber, J., Jones, R., Liu, W. B., Meeroff, D. E., Mitsova, D., Nagarajan, S., Oglesby, G., Polsky, C., Su, H., Suarez, E., Teegavarapu, R., Weaver, J., Xie, Z. X., Yong, Y., \& Zhang, C. Y. (2021). A Framework for a SubwatershedScale Screening Tool to Support Development of Resiliency Solutions and Flood Protection Priority Areas in a Low-Lying Coastal Community. Journal of Geoscience and Environment Protection, 9, 180-205. https://doi.org/10.4236/gep.2021.910013

Received: June 12, 2021

Accepted: October 26, 2021

Published: October 29, 2021

\begin{abstract}
Flood risk analysis is the instrument for local officials to create a sound strategy and adaptation plans for the impacts of inundation due to heavy rains, climate change and sea level rise. Hence, cities with aging infrastructure are retrofitting their stormwater management systems to mitigate the impacts. However determining the most at risk areas and the options for corrections is more challenging. As a result, there is an urgent need to develop a screening tool to analyze watersheds and identify the most at-risk areas. High-quality, open source data and sophisticated spatial analysis techniques allow engineers to create innovative ways to conduct watershed wide inundation analysis. In this study, the investigators developed a screening tool to identify at-risk properties by combining readily available data on topography, groundwater, surface water, tidal information for coastal communities, soils, open space, and rainfall data. Once the screening tool is developed, the means to identify and prioritize improvements to be funded with scarce capital funds is the next step. A tool box of solutions was developed to address flood risk and vulnerability. Testing of the screening tool was conducted in Broward County, Florida and shows encouraging results. Comparison with FEMA Flood maps and repetitive loss mapping indicates that the process works in a coastal community. The framework appears to be viable across cities that may be
\end{abstract}


Copyright $\odot 2021$ by author(s) and Scientific Research Publishing Inc. This work is licensed under the Creative Commons Attribution International License (CC BY 4.0).

http://creativecommons.org/licenses/by/4.0/ inundated with water due to sea-level rise, rainfall, runoff upstream, and other natural events.

\section{Keywords}

Flooding, Watershed, Flood Modeling, Screening Tool, Risk, Infrastructure

\section{Introduction}

According to the Federal Emergency Management Agency (FEMA), over 98\% of counties in the United States have experienced a previous flooding event, and just one inch of water can cause up to $\$ 25,000$ in damage (FEMA, 2017). To meet the longer-term goal of protecting life and property, FEMA created the National Flood Insurance Program's (NFIP) Community Rating System (CRS) in 1990, to encourage community floodplain management activities. As of 2017, nearly 3.6 million policyholders in 1444 communities participate in the CRS program, but this is only $5 \%$ of the over 22,000 communities participating in the NFIP (FEMA, 2017). Florida has nearly one-half of those flood risk policies.

Under the CRS program, flood insurance premiums are discounted to reward community actions that meet the three goals of the CRS, which are to 1) reduce flood damage to insurable property, 2) strengthen and support the insurance aspects of the NFIP, and 3) encourage a comprehensive approach to floodplain management. The Florida Division of Emergency Management (FDEM) and FEMA funded development of template and prototype watershed master plans (WMPs) to improve the safety of the public, reduce property losses, and limit economic disruption while providing an annual savings of $\$ 60$ million in discounted premiums for communities where the watershed plans could improve the community rating from a class 5 to a class 4 . The grant funded development of a consistent framework to create WMPs across the state.

Defining flood risk due to compounding hydrographic influences and developing a roadmap to mitigating this risk are the central concerns of a WMP exercise. This requires a spatial model for risk considerations, which is distinctly different from developing a model of predicted averages of groundwater/surface water values. Instead, the model should be conceptualized as an average of the in situ observed extremes that considers a high groundwater table, soil conditions, land development, surface water elevations, rainfall events, and if applicable king tides, climate change (sea level rise particularly), and storm surge. These conditions include LiDAR-based topography, groundwater levels, tidal and surface water levels, soil storage, land cover/imperviousness, precipitation, sea level rise, storm surge, and existing stormwater infrastructure. With these inputs, a screening tool can be used to create flood risk contours that are useful for predicting areas flooded after specific rain events.

To be useful long-term, it is critical to developing an effective screening tool that can extend beyond nuisance flooding events to those long-range events that 
call for structural changes to protect economic and social institutions along with critical infrastructure and property assets. In addition, a reading of the FEMA, NFIP and CRS guidelines indicates that these assessments should be at the HUC 12 level ( $\sim 50 \mathrm{sq} \mathrm{mi}$ or less) as opposed to the water management district and TMDL basins typically used for state planning purposes in Florida. Therefore, scalability is an important consideration as the screening tool must be able to provide information at the watershed level, and also be able to drill down to the subwatershed level to identify flood-prone areas that might not have flooded recently but have are at risk to do so under certain conditions.

For the case of south Florida, there is little soil storage capacity due to the combination of very flat topography and high water table elevations that provide a direct relationship between ground and surface waters (Bloetscher \& Wood, 2016; Bloetscher \& Romah, 2015; Wood, 2016; E Sciences, 2014; Romah, 2011). Wood (2016) used LiDAR and groundwater measurements on a given day, with the requisite high tides on that day, to create a GIS surface layer to predict flood risk. As a part of the process, Romah (2011) found a 1:1 relationship between tidal rise and groundwater elevations using the method discussed in Chang et al. (2011). This behavior was later confirmed for barrier islands, when E Sciences (2014) similarly evaluated flood risk for Miami Beach, FL using the 99th percentile tide event associated with king tide in Fall.

Outside southeast Florida, coastal flooding events are influenced by other dynamic processes (Sweet et al., 2017), such as from waves, storm surge, and their effects (Stockdon et al., 2006; Serafin \& Ruggiero, 2014; Sweet et al., 2017), local rainfall (Wahl et al., 2015), elevated groundwater (Romah, 2011, Rotzoll et al., 2013; Wood, 2016; Sukop et al., 2018), or river runoff (Moftakhari et al., 2017). In studying the potential impacts of flooding in a watershed, a certain set of ongoing strategies would appear to be useful for ultimately protecting the economic and social viability of communities, minimizing risks to residents, identifying vulnerable assets, and providing insurance and banking entities with a degree of confidence in local community protection efforts. These strategies are not the same for any two communities, and the outcomes vary.

The key for local officials is to be able to identify flood-prone areas quickly-including those that might not have flooded recently but may pose a significant risk for flooding under certain conditions. The existing literature on developing screening tools for conditions similar to south Florida have not previously taken into consideration soil storage capacity based on rainfall and groundwater level. As a result, the goal of this paper is to refine screening tool methods further by incorporating the surface waters that influence groundwater in southeast Florida, adjust for true soil storage, and model a series of design storms as a means to better predict flood risk for events not related to sea level rise. Independently generated FEMA flood maps will be used to compare the results of the model in Broward County, FL. This screening tool could then be used to better identify zones at the subwatershed-level to target for mitigation strategies within a watershed master planning framework. 


\section{Methodology}

The screening tool conceptually depicted in Figure 1 builds on prior work by Bloetscher et al. (2021), Bloetscher and Wood (2016), Wood (2016), Bloetscher and Romah (2015), E Sciences (2014), Romah (2011), and Zhang et al. (2020). Romah (2011) and Wood (2016) defined flood risk using LiDAR and groundwater measurements on a given day, with the requisite high tides on that day. Pertinent information and technical data was obtained from the regional water management district (South Florida Water Management District, 2001) for groundwater table elevations and surface water gage heights; tidal information for coastal areas from the National Oceanic and Atmospheric Administration (NOAA); soil maps from United States Department of Agriculture (USDA), and topographic data from various sources LiDAR mapping and rainfall totals from NOAA. The design storm for calculation purposes was the 3-day, 25-year event, which is the standard used by SFWMD. The 1-day, 100-year storm was also modeled as this is a required storm for NFIP purposes (note that the 3-day, 25-year storm results are similar). NFIP also requires the much less rainfall intensive 1:10 year storm.

To be useful, the screening tool must be able to drill down from a regional watershed or subwatershed scale down to smaller community-level scales for sufficient detail required for development of a watershed master plan. The plans themselves require the following basic steps:

1) Identify the subwatershed boundaries using the USGS subbasin hydrologic unit code (HUC) definitions. For a subwatershed to be creditable in the CRS program, it should generally not exceed 50 square miles, but should be sizable enough to address the water quantity in the basin (Carlton, 2021).

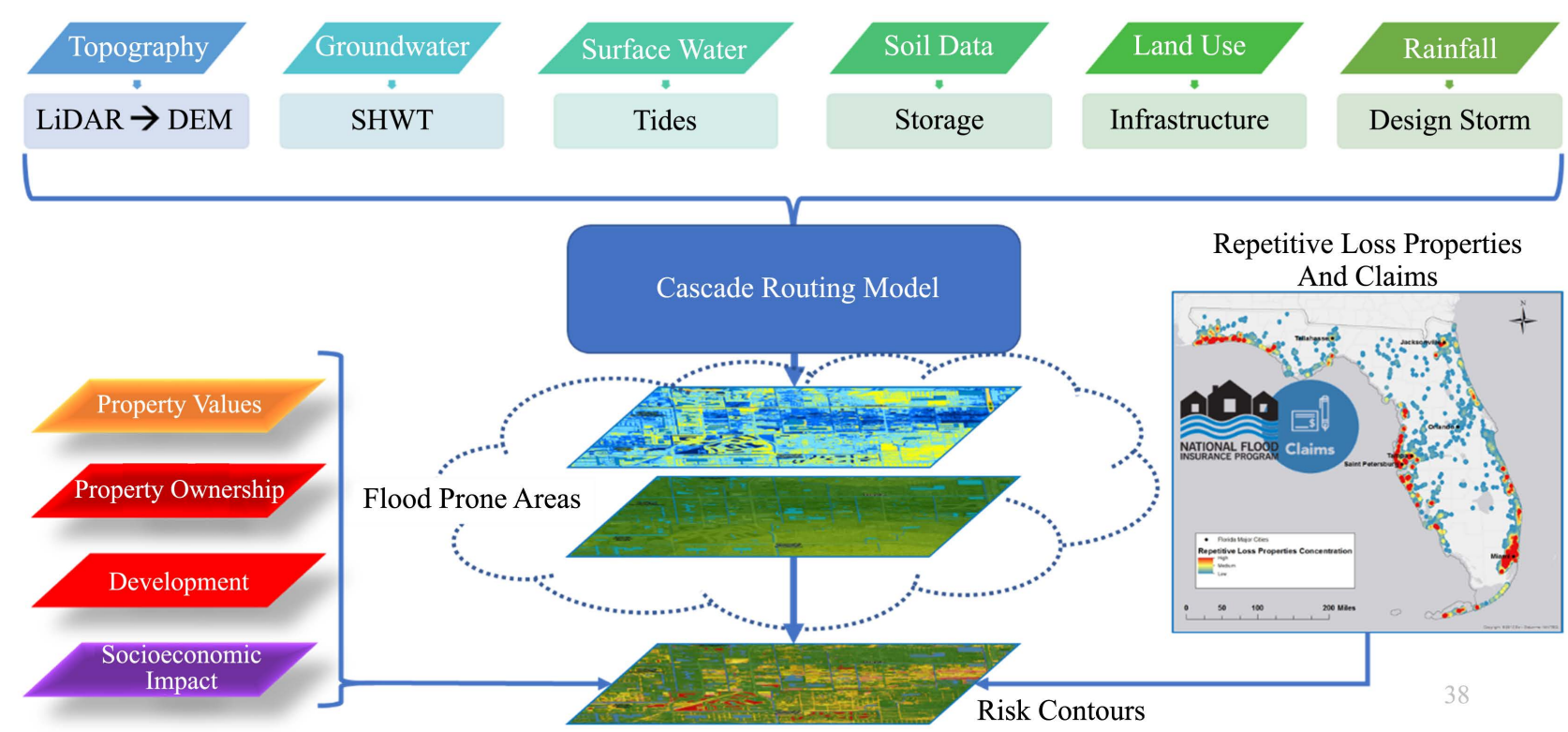

Figure 1. Databases that contribute information layers in GIS that are integrated through modeling software to create the flood risk screening tool. 
2) Identify key stakeholders (governments, community organizations, etc.) and existing planning supports or regulations that will impact the subwatershed.

3) Acquire comprehensive planning, zoning, land use, flood control and other policy frameworks for future land use that contribute to flood risk.

4) Identify an appropriate planning level of service and obtain the following design storms: a) 1-day, 10-year, b) 3-day, 25-year, and c) 1-day, 100-year storm events to determine extent and severity of flooding. Where applicable, sea level rise, king tides, etc. should also be modeled with each precipitation event.

5) Acquire recent aerial photographs of the basin (note historical aerial photos may be helpful in developing projections for development).

6) Acquire FEMA flood insurance rate maps and repetitive loss data.

7) Acquire GIS data for roads, property, topography, waterways (streams, lakes, canals and rivers), groundwater levels, sea levels and tidal data (as applicable), land use, future land use, open space, impervious areas, structures (where available) and storm surge (coastal communities).

8) Acquire information of local stormwater infrastructure and input to the GIS maps.

9) Identify applicable standards for stormwater design-for example, permits or requirements in place requiring communities to meet a given flood protection event (3-day, 25-year storm, for South Florida). Note detailed routing software may be required to accomplish this task with accompanying costs.

10) Identify water that flows from another community and outlets of water that receive the overflow.

11) Identify drainage issues within the jurisdiction caused by current and future development.

12) Identify properties at risk of flooding (county property appraiser maps-note specific property identification must be avoided in publicly available maps).

13) Identify solutions that may be applicable for implementation in a given basin.

14) Prioritize properties based on critical infrastructure consequences of flooding and probability of flooding.

15) Identify funding sources for these solutions and establish a schedule for implementation.

16) Develop a capital improvement program for infrastructure.

17) Compile comments from stakeholder groups.

18) Develop a maintenance plan for infrastructure and monitoring results (MS4 permits are an example that could be used).

19) Seek approval of plans from stakeholder governments and NFIP.

Localized infrastructure improvements in small subwatersheds will have more impact on the results than in larger watersheds, meaning the ability to scale up or down, while incorporating associated infrastructure, is required. At the same time at the neighborhood level, under-designed piping, which will not impact the regional flood models, will be identified as failing to meet the level of service standard for the subwatershed and cause major flood concerns. 


\section{Surface Topography Development}

Topography is a key parameter that influences many of the processes involved in flood risk assessment, and thus, up-to-date, high-resolution, and high-accuracy elevation data are required. As specified by the FEMA Risk Mapping, Assessment, and Planning (RiskMAP) protocols, 1-meter (2015 to present) and 1/9 arc-second ( 3-meter) (2010-2015) LiDAR DEMs were acquired from the USGS 3D Elevation Program (3DEP) using the National Map Viewer

(https://viewer.nationalmap.gov/basic/). FEMA has adopted the Quality Level 2 (QL2) data as a standard as defined in the USGS LiDAR Base Specification v1.2 (Heidemann 2014), which is provided through the USGS 3DEP (FEMA, 2016). QL2 from the National Enhanced Elevation Assessment (NEEA), which serves as the basis for the USGS 3DEP, was developed using airborne LiDAR point density of 2 points per square meter allowing for a high accuracy and enhanced resolution of derivatives. The 1-meter Digital Elevation Model (DEM) has a target non-vegetated vertical accuracy of $19.6 \mathrm{~cm}$ at the $95 \%$ confidence level, which is consistent with the 3DEP QL2 vertical accuracy threshold of plus or minus ( \pm ) $10 \mathrm{~cm} \mathrm{RMSEz}$ (Arundel et al., 2015). The 3-meter DEM products have a vertical accuracy between $22 \mathrm{~cm}$ and $30 \mathrm{~cm}$ that meets the specifications of FEMA Elevation Guidance (Document 47) for flood risk analysis and mapping (FEMA, 2016). The source data included NOAA flights in 2018, plus local data of various dates. Where the maps overlapped, they were stitched together using GIS smoothing.

\section{Groundwater}

For situations in which groundwater is under the influence of surface water, it is necessary to collect groundwater table elevation data to calculate soil storage capacity. Since well density varies considerably, interpolation of data was required to create a groundwater surface developed using groundwater data from 2005 to 2018. To establish a common date for modeling purposes, the recorded groundwater table elevations were sorted in ascending order to determine the $98^{\text {th }}-100^{\text {th }}$ percentile date of occurrence in Excel', following the manual procedure detailed in Romah (2011). In this study, the manual procedure was automated using a python code to process the groundwater data more efficiently. Outliers and anomalous groundwater levels in the database are initially identified (e.g. catastrophic storm events) and replaced by region-specific mean values based on observations available from the nearest wells. Missing date-specific data are estimated using simple temporal interpolation based on observations available in time. If a station (or monitoring well) data contains missing data, it is not used in the generation of the groundwater surface. The full process is outlined in Zhang et al. (2020).

\section{Surface Waters/Tides}

Because the water table is so shallow ( $<4 \mathrm{ft}$ bls) in the southeast Florida study area, surface waters tend to directly influence groundwater (Romah, 2011; Chang et al., 2011). E Sciences (2014) and Bloetscher (2012) found that the groundwater elevation is also consistent with high tides as opposed to average tides for a 
boundary condition. As a result, projecting groundwater levels will indicate infrastructure with a greater vulnerability for flooding where water, sewer, stormwater and transportation infrastructure in low-lying inland areas may be compromised faster due to the loss of soil storage capacity. Therefore, once the common date for the groundwater surface is determined, surface water levels and tidal data can be obtained for that same date ( \pm 3 days, in the event the water elevation in the canals was deliberately lowered by the water management district authorities). Surface water stage heights for canals and other important water bodies were obtained from DBHYDRO, which is a database system used by SFWMD to record water quantity and water quality data. The canals form boundary conditions for the screening tool on the edges of the basin and affect localized groundwater. Besides groundwater and surface water levels, to set a boundary for the coastal areas, the high tide on the common date should be chosen. The tidal data for the common date is obtained from NOAA tide data (https://tidesandcurrents.noaa.gov/).

Once the common date is found, the water levels in all wells from the modified database and the surface water stations, canals, lakes, and ocean are used to create the groundwater surface in GIS. Spatial interpolation using a stochastic variance-dependent interpolation is used to estimate groundwater levels at points of interest or for the generation of the surface (Romah, 2011 and references therein; Zhang et al., 2020 and references therein). A subset of available data is used for the creation of a validation dataset, and the rest of the data is used for calibration (i.e., estimation of parameters of the interpolation model). Where the coast is present, the coast is used as a constant head boundary. The geostatistical Bayesian krig was used from ArcMap 10.7 to create the groundwater layer.

Sea level rise also must be included for coastal ares. The NFIP program looks for a model of the NOAA mean medium high 2100 value. For southeast Florida, this value is $5 \mathrm{ft}$ based on Figure 2 (the sea level rise projection from NOAA at https://tidesandcurrents.noaa.gov/publications/techrpt83_Global_and_Regional SLR_Scenarios_for_the_US_final.pdf). Note that surge modeling can be done, but since the objective was storm based, tropical storm induced flooding was not done as a part of this phase of the project.

\section{Soils}

Soils can store additional water before becoming saturated if there is sufficient distance between the ground surface and the water table and if the soils are capable of infiltrating the water. Soil data is obtained from the USDA gSSURGO database and is interpreted to determine whether water can be absorbed or will run off. This is a critical issue for precipitation modeling. The soil maps are incorporated as a GIS layer in the overall mapping effort. The USDA gSSURGO database contains all the original soil attribute tables from the USDA National Cooperative Soil Survey (NCSS) (Soil Survey Staff, 2020) in the Environmental Systems Research Institute, Inc. (ESRI') file geodatabase format. This allows for 


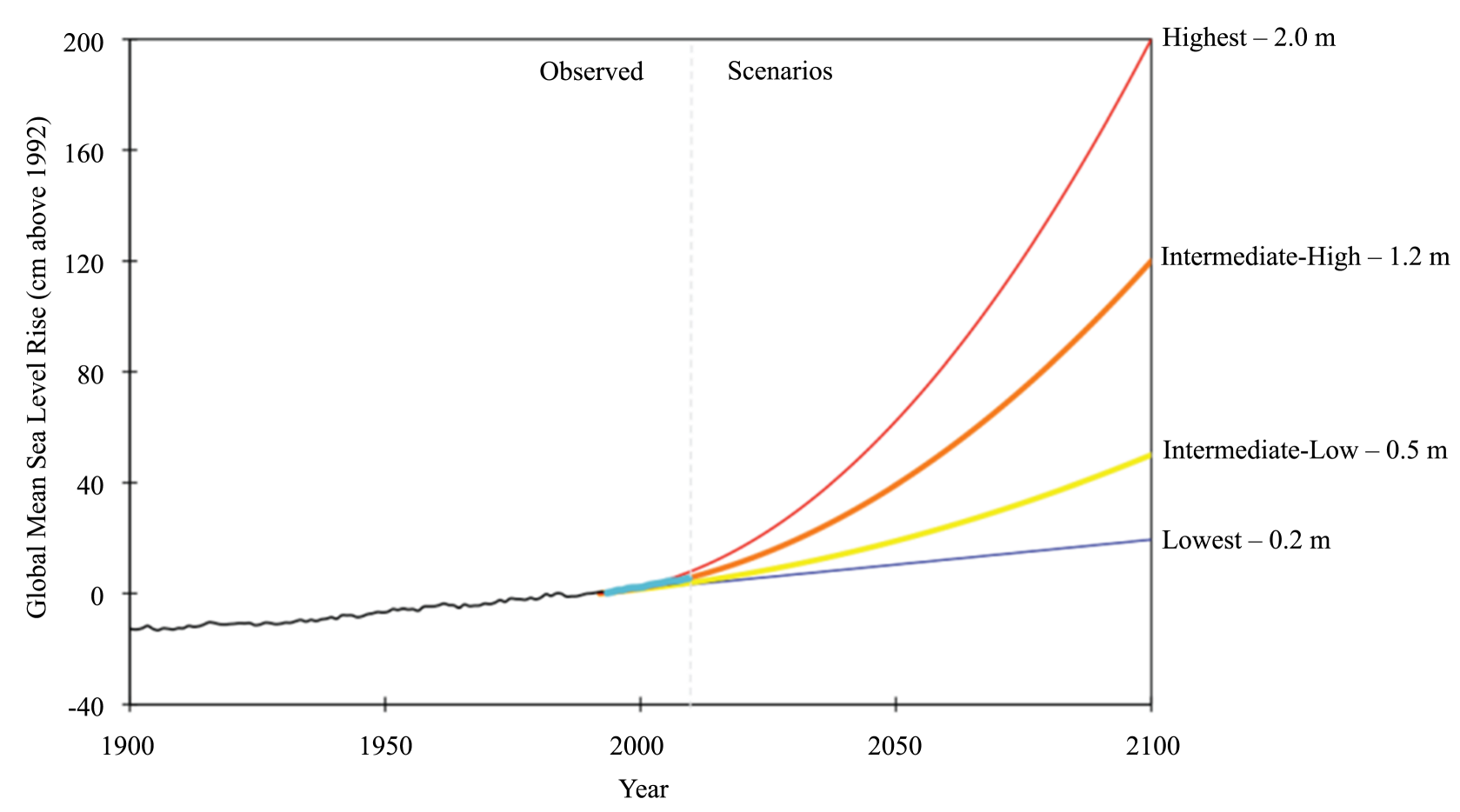

Figure 2. Graphic of sea level rise projections from NOAA (2017).

(https://tidesandcurrents.noaa.gov/publications/techrpt83_Global_and_Regional_SLR_Scenarios_for_the_US_final.pdf)

statewide or even Conterminous United States (CONUS) tiling of data. An important addition to this format is a 10-meter raster (MapunitRaster_10m) of the map unit soil polygon feature class, which provides statewide coverage in a single GIS layer.

To find the unsaturated zone, the groundwater layer, as influenced by the surficial canals, is subtracted from the topographic layer to show the apparent unsaturated zone. In Broward County much of the area is expected to show minimal differences between the ground surface and the water table elevations in the fall, except along the coastal ridge. The void space comes from a statewide GIS file of soil void capacity. The unsaturated zone layer is multiplied by void space to create the soil storage capacity layer.

\section{Land Cover}

The National Land Cover Database (NLCD) provides nationwide data on changes in land cover at a $30-\mathrm{m}$ resolution with a 16-class legend based on a modified Anderson Level II classification system (Jin et al., 2019). The database is designed to provide cyclical updates of United States land cover and associated changes. The latest release of NLCD products named NLCD 2016 is used. For the conterminous United States, NLCD 2016 contains 28 different land cover products characterizing land cover and land cover change across 7 epochs from 2001-2016, urban imperviousness and urban imperviousness change across 4 epochs from 2001-2016, tree canopy and tree canopy change across 2 epochs from 2011-2016 and western U.S. shrub and grassland areas for 2016. Large water bodies such as the Intracoastal Waterway and canals are delineated by NLCD 
dataset, but it does not have sufficient resolution of smaller waterbodies and impervious surfaces. Therefore, a statewide land use land cover dataset (FLUCCS-FSWMD, 2012) compiled by the Florida Department of Environmental Protection (FDEP) was also collected. This dataset integrates land use land cover data products provided by the regional water management districts in Florida based on manually interpreted fine resolution aerial photography. Compared to the NLCD dataset, the FDEP land use land cover product has a finer delineation of land cover types. This dataset was used to refine water bodies and impervious surfaces, where soil water holding capacity is considered as zero in the screening tool. The impervious areas, the water mask layer, the soil water holding capacity ratio layer, and the soil storage capacity layer allow calibration of the model to account for the actual amount of water that can enter the soil before filling it; these layers represent the real characteristics of the area (refer to Figure 1).

\section{Precipitation}

Precipitation is available from NOAA and as apart of many software packages for the State of Florida. For the purposes of thisproject, NFIP desires a comparison on the 1-hr, 100-year, or 3-day, 25-year and 1:10 year events. The SFWMD includes theser values in their Environmental Resources permitting manual (https://www.sfwmd.gov/document/environmental-resource-permit-informatio n-manual). Rainfall records were derived from NOAA records available from FAU's cwr3 website.

\section{Existing Infrastructure}

For flood modeling to provide useful results, modeling must include relevant infrastructure. As Table 1 notes, scaling is relevant. Localized infrastructure improvements in small watersheds will have more impact on their results than in larger watersheds. Hence there is some degree of economy of scale-larger infrastructure will have wider effects than a single catch basin for example. However extensive, underdesigned piping will be identified as failing to meet the level of service standard.

Table 1. Scale of infrastructure to include in model.

\begin{tabular}{|c|c|c|}
\hline Level of Modeling & $\underline{\text { HUC }}$ & Examples of Infrastructure of Concern \\
\hline TMDL Region/USGS Watershed & 8 digit & Major canals, dams, large rivers, lakes, and ocean \\
\hline Subwaterhed & 12 digit & $\begin{array}{l}\text { Primary and secondary canals, dams, large rivers, } \\
\text { lakes, ocean, streams, smaller lakes, } \\
\text { large bridge/culvert structures, } \\
\text { draiange operations/staging }\end{array}$ \\
\hline Community & $\mathrm{n} / \mathrm{a}$ & $\begin{array}{l}\text { Rivers/streams/canals, interceptors/large ditchs, } \\
\text { neighborhood lakes/large retention/detention areas, } \\
\text { major roadway conveyances }\end{array}$ \\
\hline Neighborhood & $\mathrm{n} / \mathrm{a}$ & $\begin{array}{l}\text { Catch basins, swales, } 15 \text { " piping, crowns of road, } \\
\text { culverts under driveways, } \\
\text { local retention/detentaion areas }\end{array}$ \\
\hline
\end{tabular}




\section{Flood Mapping}

A basin is defined as an area where all the water that falls via rainfall stays in an area and travels to an outlet. The areas of the basin and the longest time it takes the runoff to travel to the most distant point of discharge must be estimated. Putting the prior datasets together, is a software package (CASCADE 2001) developed by SFWMD (2001) to predict flooding. CASCADE 2001 is a GIS-based multi-basin hydrologic/hydraulic routing model that permits investigators to analyze different storm events to determine potential flooding. The boundaries are critical for basin studies and must be chosen carefully. The model requires the following input:

- Topography

- Groundwater elevations

- Surface water/Outlet locations

- Soils

- Development intensity/land cover

The screening tool predicts how areas with low elevations may be affected by a selected rainfall event (1-hr, 100-year, or 3-day, 25-year, or other event), inundation from the ocean directly, rising groundwater levels, and the inability of inland areas to drain. Romah (2011) defined vulnerability maps using the definitions of the U.S. Army Corps of Engineers (USACE) that are "Vulnerable," "Potentially Vulnerable," or "Less Vulnerable". However for this application, a modified approach was used that defines flood risk as the probability of inundation based on ground elevation data. A major advantage of this approach compared to inappropriate bathtub mapping performed by others is that it takes into consideration the vertical accuracy error in the elevation datasets, which may vary depending on the available data spatial resolution. Errors in elevation data are typically reported as either the RMSE or Accuracy (FEMA, 2003). In addition, RMSE approximates the population standard deviation (SD) when the data are not biased (i.e. the mean error is zero). The uncertainties associated with the DEM vertical accuracy, estimated depths to groundwater table, and the modeling approach itself are incorporated in the RMSE computation. A z-score surface can be used to derive the probability of inundation under an assumption of a normal distribution for the measurement and modeling errors (Schmid, Hadley, \& Waters, 2014). The z-score surface from which to derive probabilities of inundation is defined as follows:

Z-Score $=[($ highest headwater height $)-($ Ground Elevation from LiDAR DEM)]/(RMSE_LidaDEM ${ }^{2}+$ RMSE_CRT2001Model $\left.{ }^{2}\right)^{0.5}$

$=($ Headwater Height - LiDAR DEM Elevation $) / 0.46$

The value of one standard deviation in the inundation modeling suggested by NOAA for the coastal vulnerability assessments is $0.46 \mathrm{ft}$ (NOAA, 2010), which is the value adopted in this work. The relationship of the inundation probability and the predicted water surface elevations is calculated as follows:

$$
\text { Probability of Inundation }=\mathrm{CDF}_{\text {normal }}(\mathrm{Z} \text {-Score })
$$


Finally, review the veracity of the model, the the flood risk probabilyt maps for the area ferived formteh Cascade model were compared to the FEMA flood maps to compare the percentage of the area that was predicted to the flooded by both methods. The subject area was Broward County, Florida (see Figure 3).

\section{Results}

Figure 4 shows the results of the LiDAR DEM processed for the subwatershed using 3 - $\mathrm{m}$ tiles with $\pm 0.1-\mathrm{m}$ accuracy. The highest points are the three sanitary landfills that are approximately $100 \mathrm{ft}$ above sea level. The water conservation areas are found along the western boundary. These water conservation areas do not receive any water from the developed area of the subwatershed.

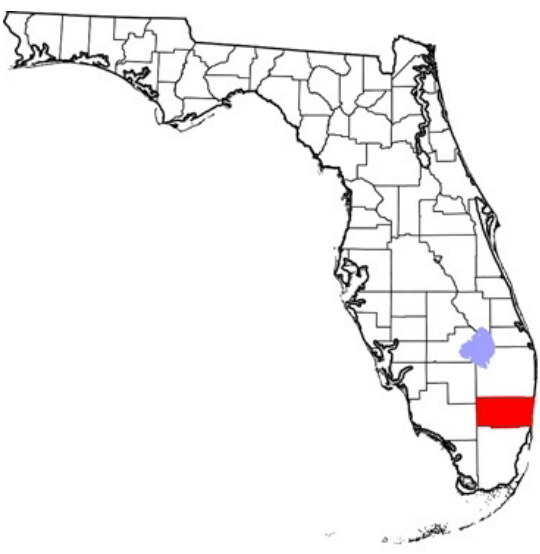

Figure 3. Location of Broward county, FL.

Broward Basin

Digital Elevation Model

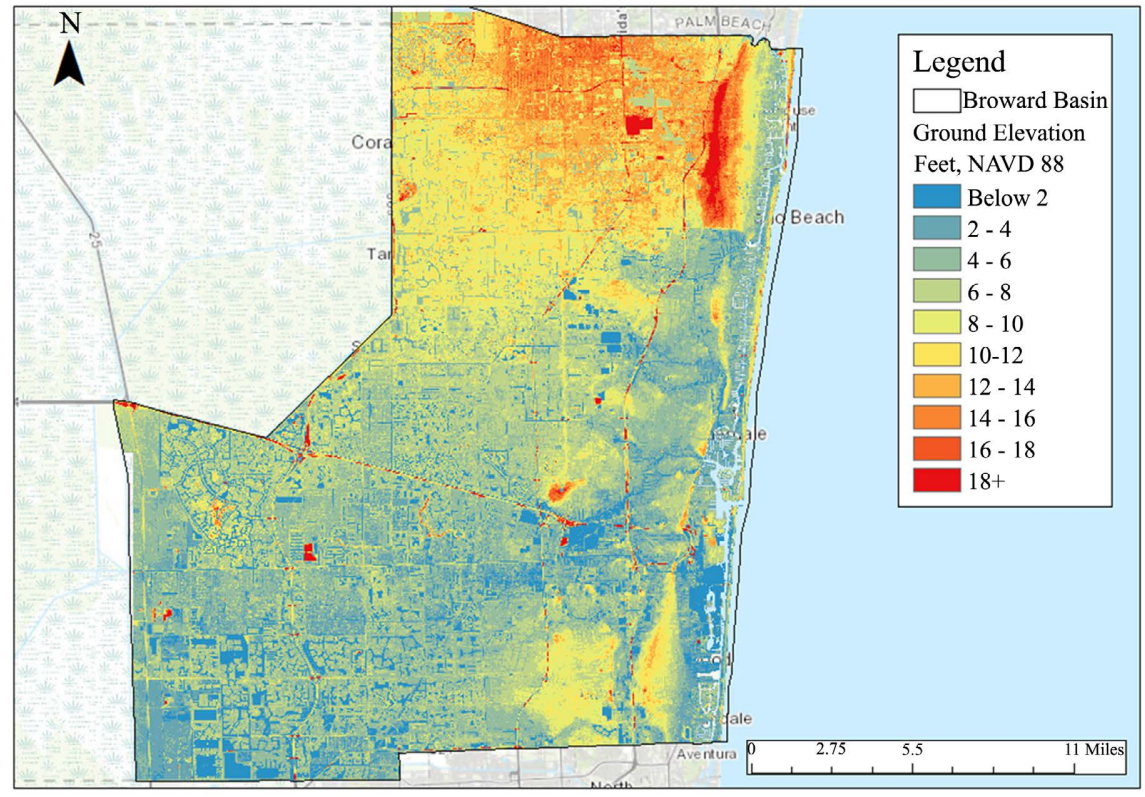

Figure 4. Topographic map of the Broward county as processed by FAU (2016 flight). Note this represents areas outside the basin. 
The drainage canals installed between 1930 and 1960 control groundwater levels throughout the subwatershed. Figure 5 shows the canals and surface water bodies in Broward County, along with the location of the structures designed to alter the groundwater level upstream, and are therefore downstream areas are open to tide. As a result, the water fluctuates with the level of the ocean. For Broward County, the tidal information demonstrated that the surface and ground water levels interact as one. Therefore, there is a need to capture groundwater data.

There are over 50 groundwater wells located in and around the subwatershed were used to develop Figure 6. Groundwater is lowest near the canals and the coastal ocean and rises with the wet season and king tides. Water shows to be lowest near the coast, as the well indicate. Southeastern Broward, was the most impacted, in part because the closest salinity structure is 10 miles from the ocean, creating a major potential for both aquifer drainage and saltwater intrusion. The 95 - 100 percentile tides occurred primarily in the September and October timeframe (by listing all tides in ascending order). The tidal peak condition occurs in the fall, which is close to the point when the groundwater levels are highest.

The unsaturated zone depth is the difference between the ground surface elevation and the groundwater table elevation layer (Figure 7). The unsaturated zone depth layer is then multiplied by the soil void ratio layer to give the actual amount of water that can enter the soil before filling it. As shown in Figure 8, most of the subwatershed has minimal soil storage capability.

Figure 9 depicts the impervious areas, which are primarily roads and structures. These are areas where water cannot seep into the soil and as a result runoff

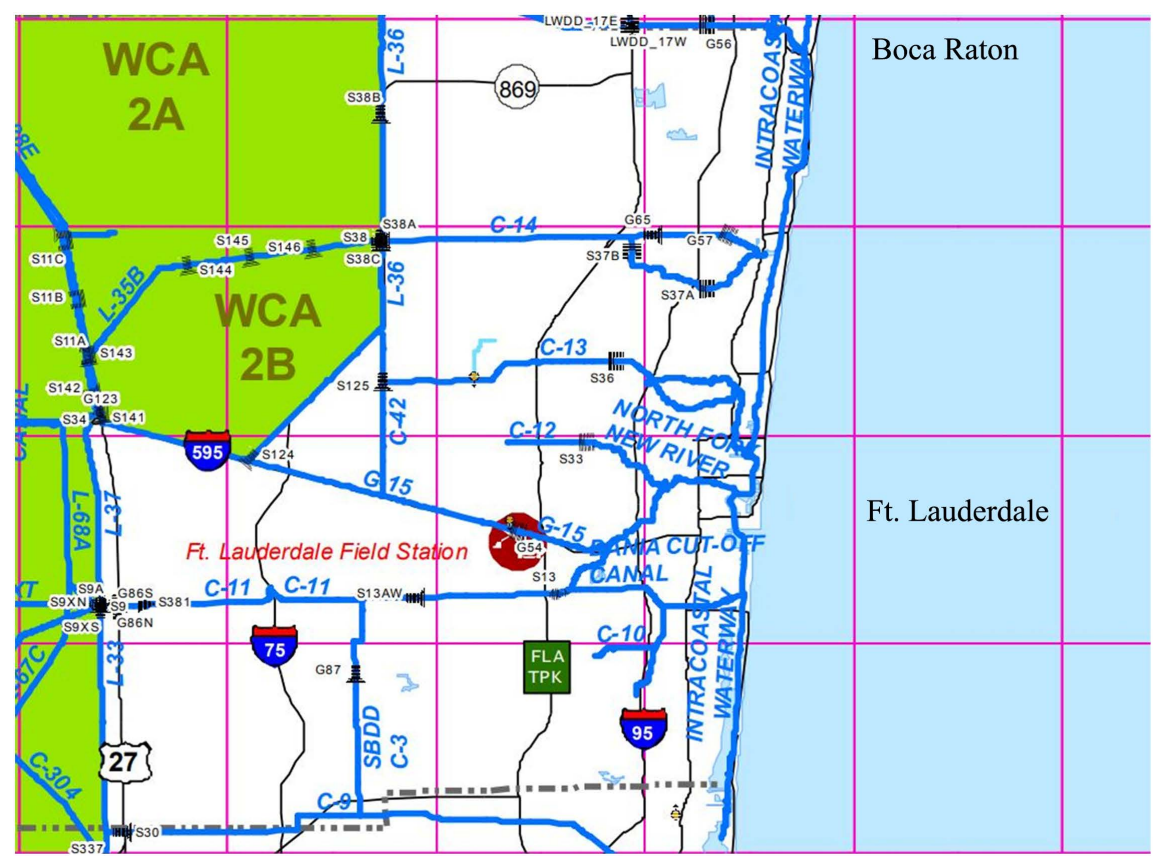

Figure 5. Water bodies and canals in Broward county (SFWMD.gov). 


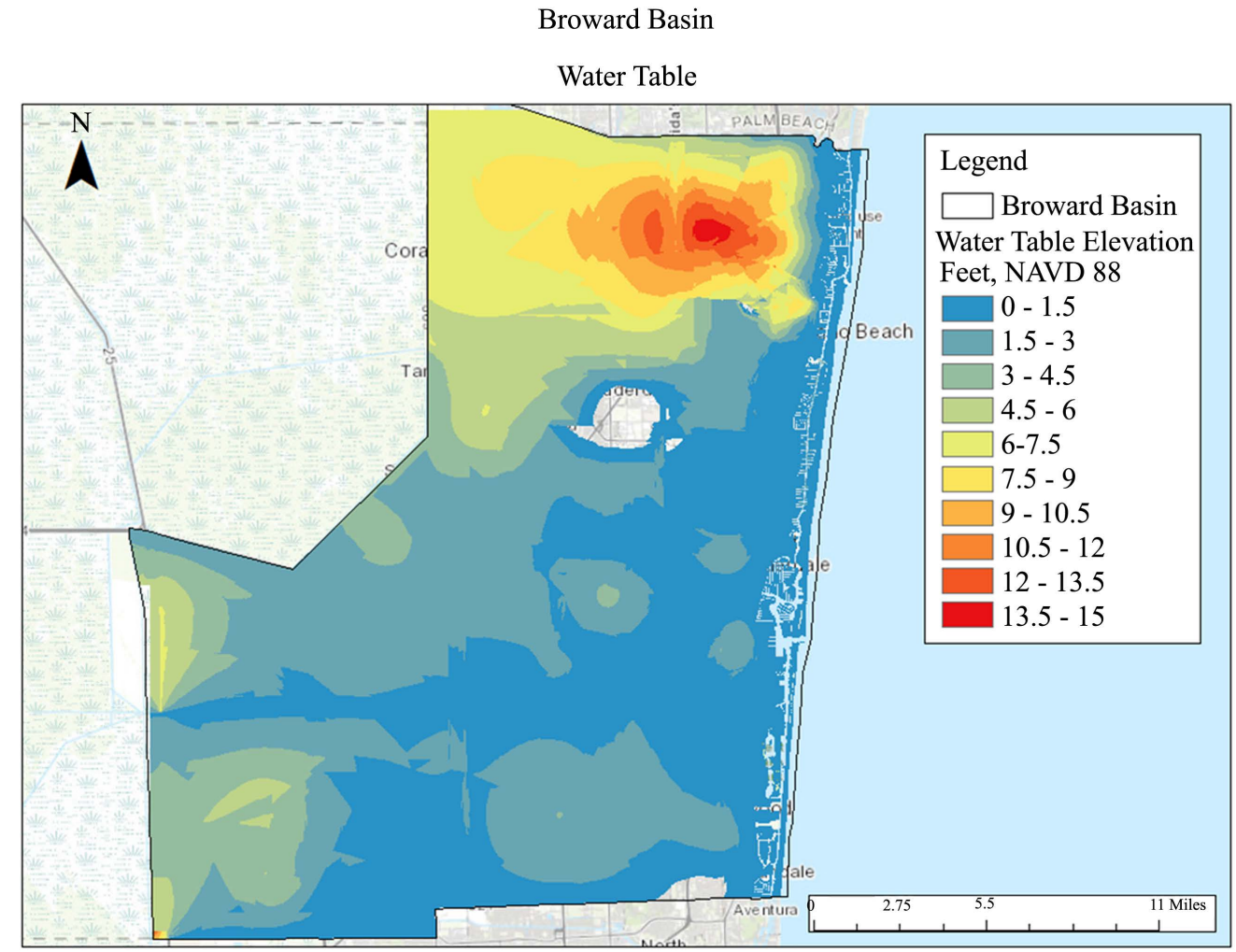

Figure 6. Elevation of the top of the surficial groundwater layer for Broward County as created by multiple linear regression analysis-elevation NAVD88, as processed by FAU.

\section{Broward Basin}

Unsaturated Zone

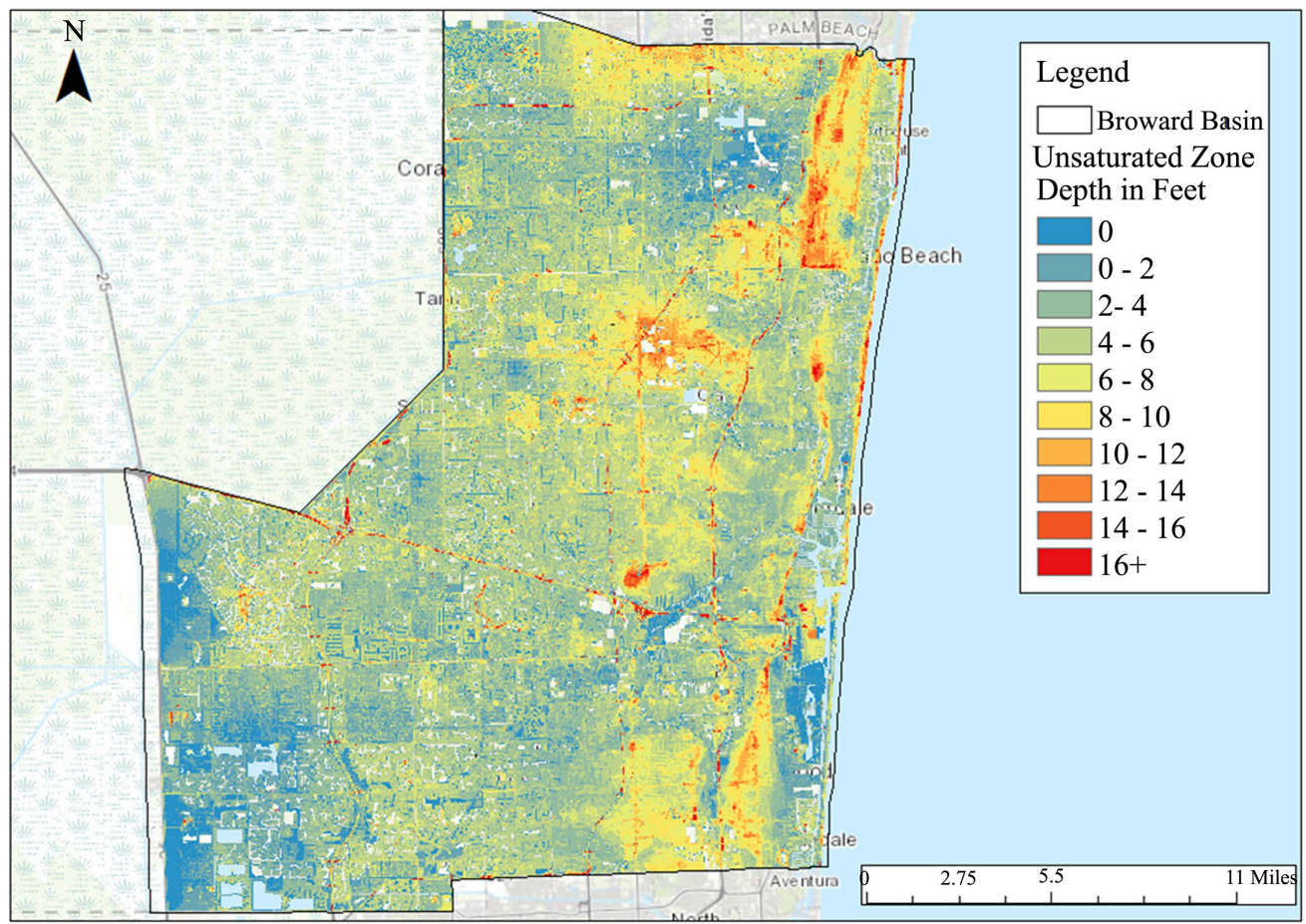

Figure 7. Unsaturated zone map for Broward county as processed by FAU. 


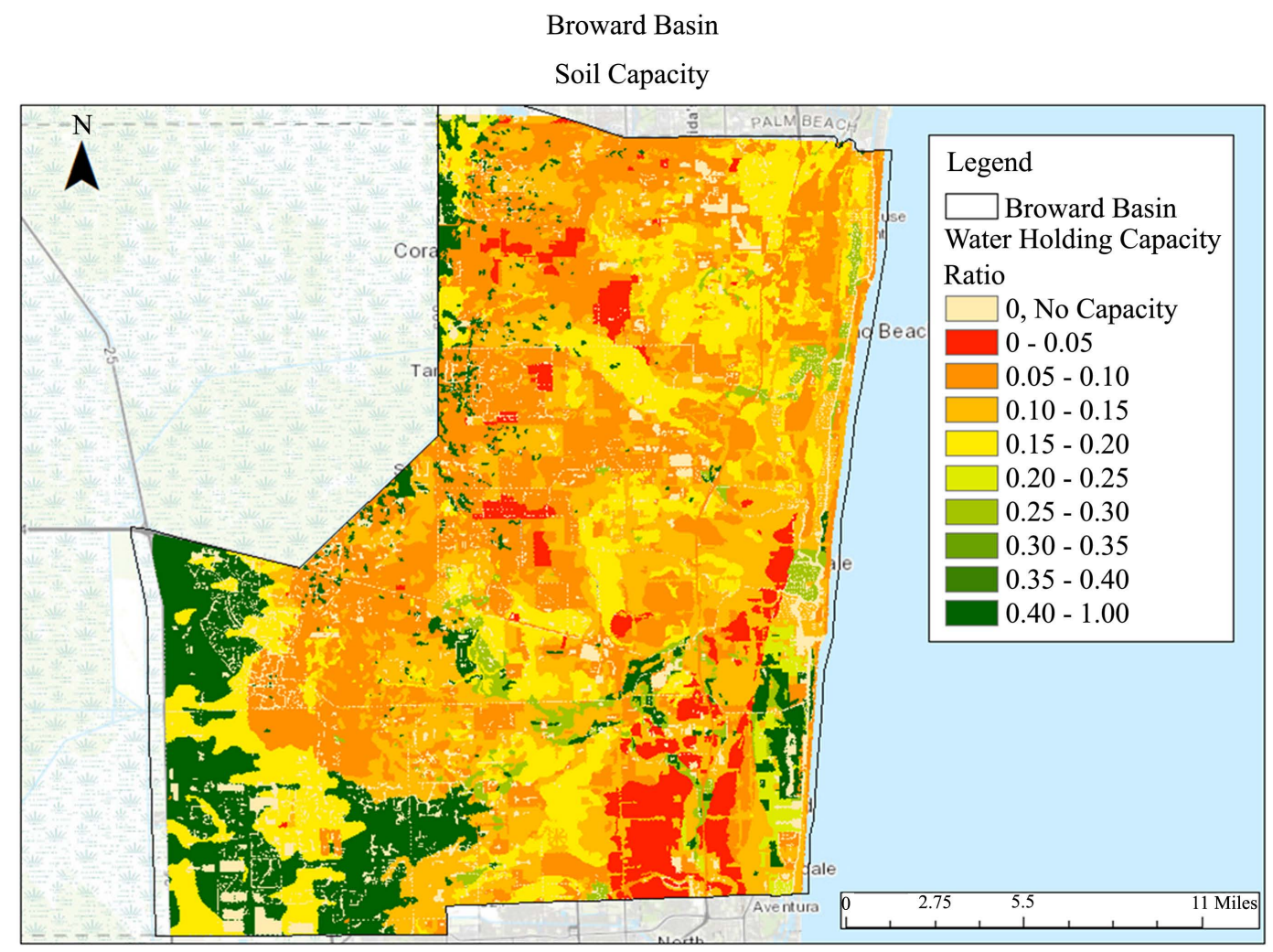

Figure 8. Water holding capacity of soil for Broward county as processed by FAU.

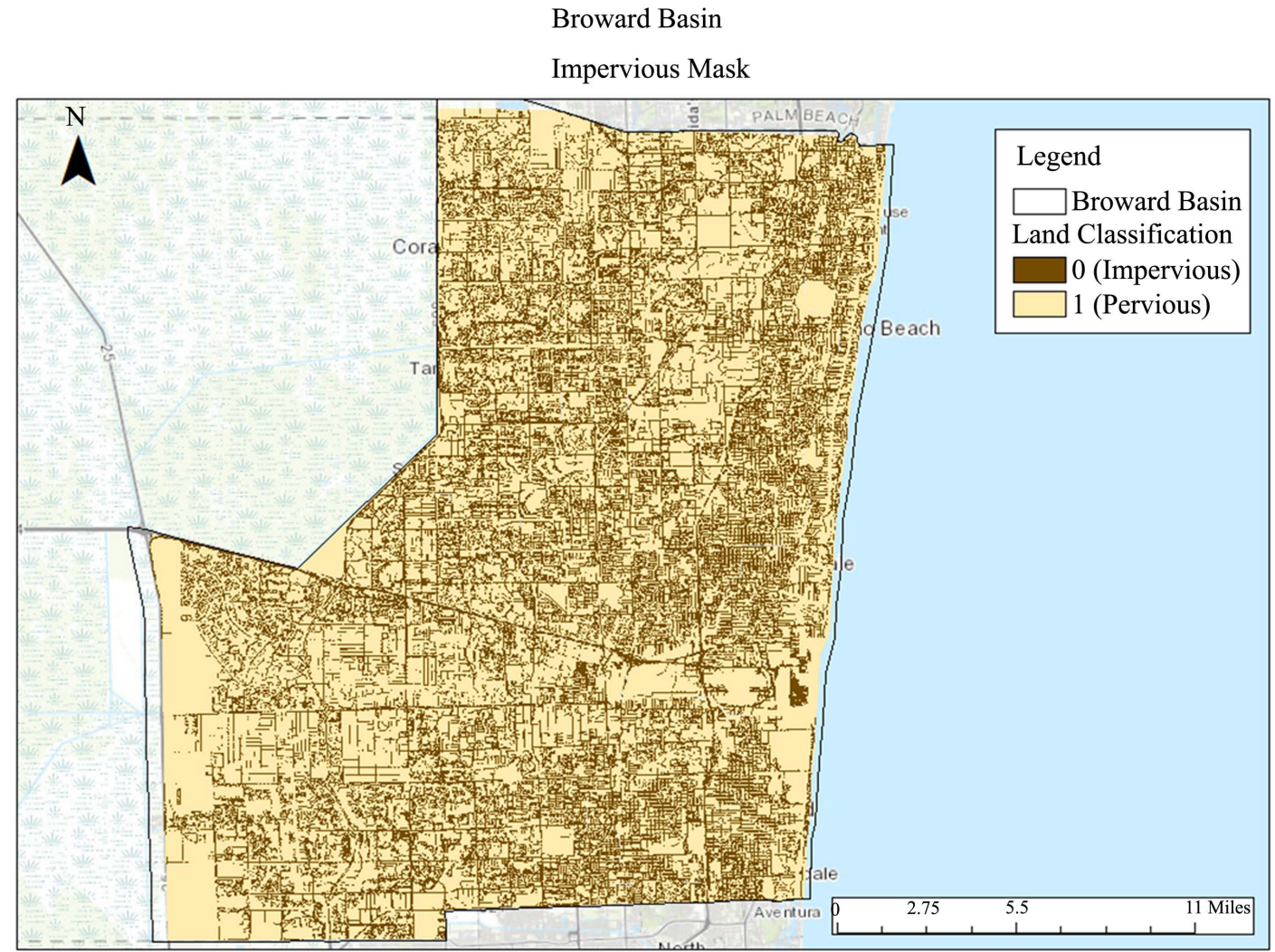

Figure 9. Impervious area map for Broward county as processed by FAU. 
to nearby unsaturated areas. Impervious areas also include water bodies (Figure 10). Based on a combination of Figures 8-10, Figure 11 shows the soil storage capacity in the County.

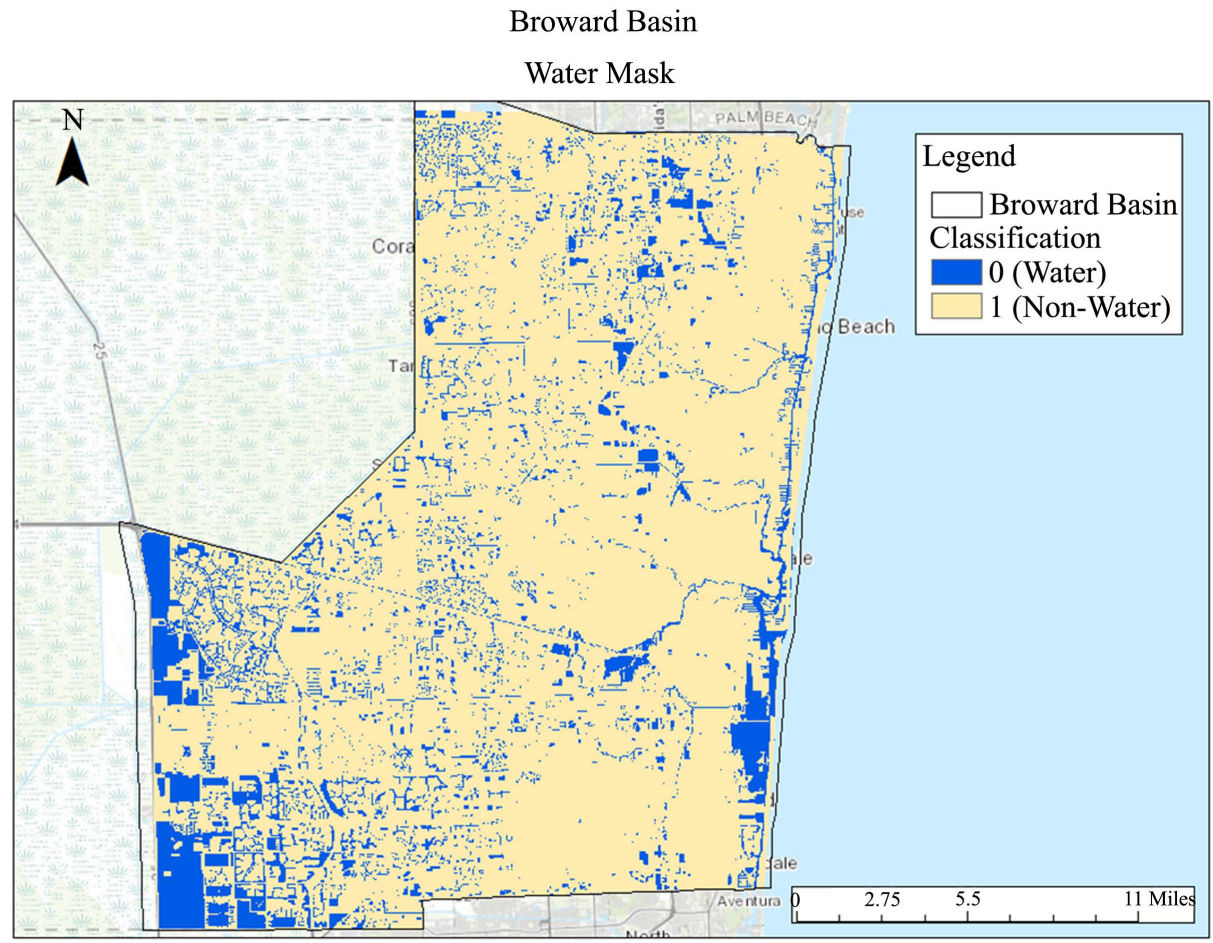

Figure 10. Waterbodies map for Broward county as processed by FAU.

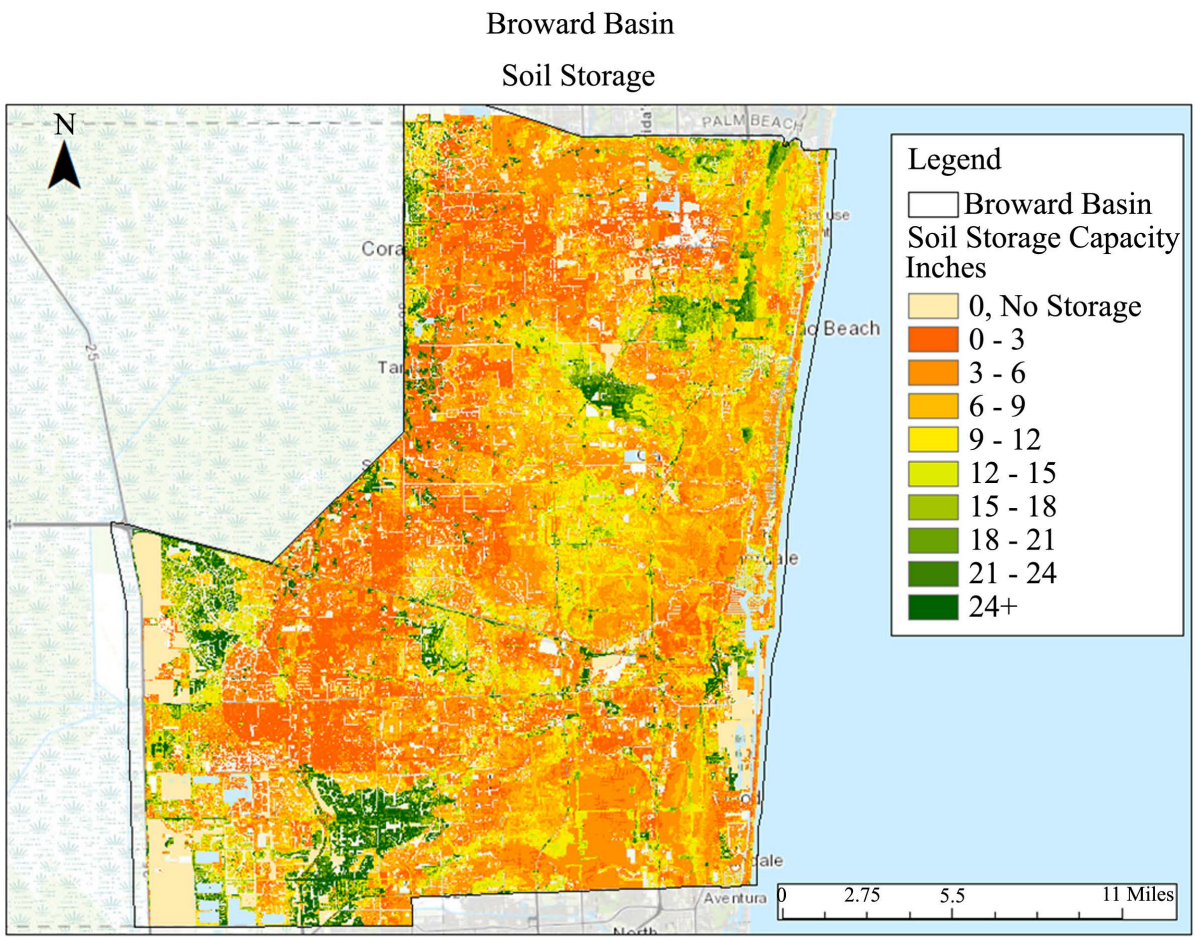

Figure 11. Ground (Soil) storage capacity-Broward county as processed by FAU. 


\section{Vulnerability to Flooding}

Figure 12 shows the 3 rainfall events modeled. The model chosen for this screening tool is Cascade 2001, which is a multi-basin hydrologic/hydraulic routing model developed by the SFWMD to determine flooding scenarios for different storm events. The software creates a glass box where water rises to a certain level and then decreases. Running the simulation requires defining the basin (HUC or sub-HUC) and input of the following data:

- Area

- Portion of area above a given elevation

- Initial ground water stage

- Longest travel time for the runoff to reach the most distance point of discharge

- Ground storage as estimated from the USDA gridded National Soil Survey Geographic Database (gNATSGO)

Ground storage $\approx$ (Water holding capacity) $\times$ (Surface elevation - GW elevation $)=2 \times($ AWS for a soil layer of $0-150 \mathrm{~cm}) / 150 \mathrm{~cm} \times($ Surface elevation GW elevation)

- Available water storage (AWS) for a soil layer of $0-150 \mathrm{~cm}$

- Average amount of precipitation that can be stored in the soil layer

Figure 13 shows the flood risk results for the subwatershed based on the same events. Note this is not the same series of events that FEMA uses: FEMA assumes a combination of sea level rise of $5 \mathrm{ft}$ and rainfall of 1:100 years (to match

\section{Broward Basin}

Varying Rainfall Frequencies

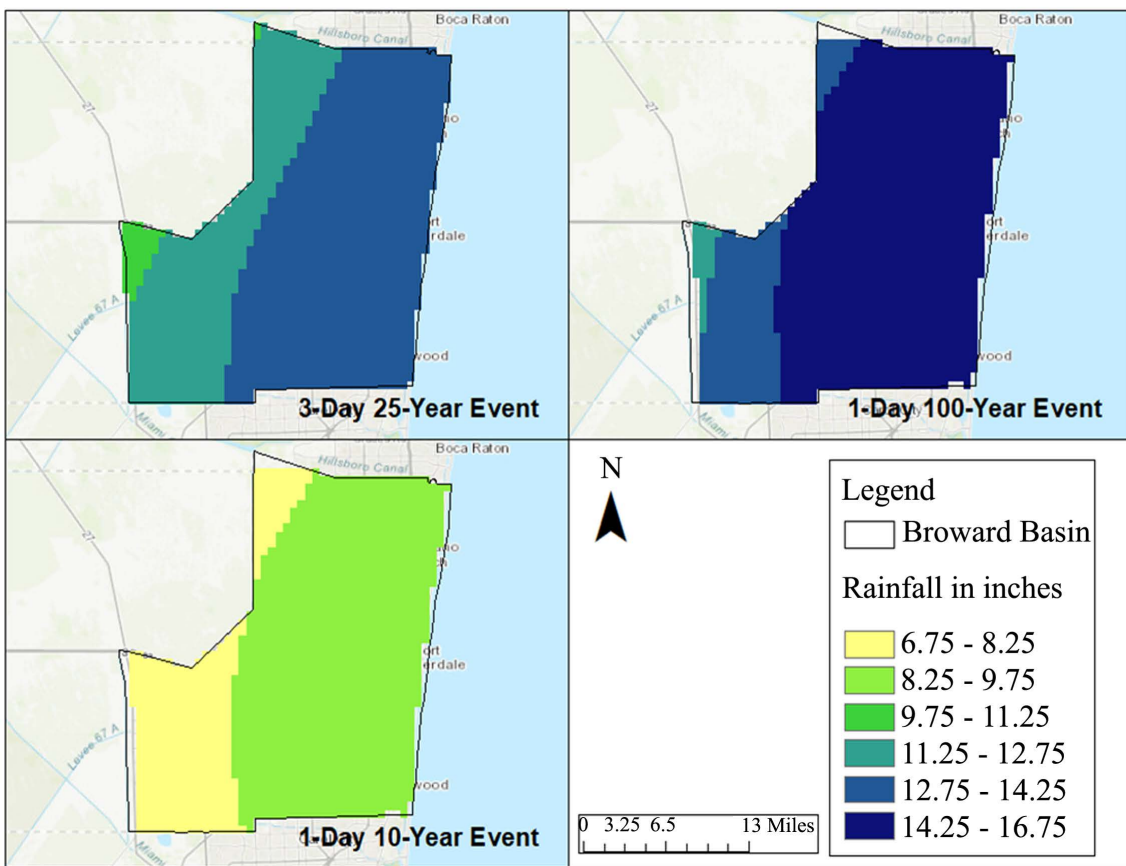

Figure 12. Rainfall events for 3-Day 25-Year, 1-Day 100-Year, and 1-Day 10-Year storm events-Broward county. 
Broward Basin

Flood Inundation At Different Flood Events

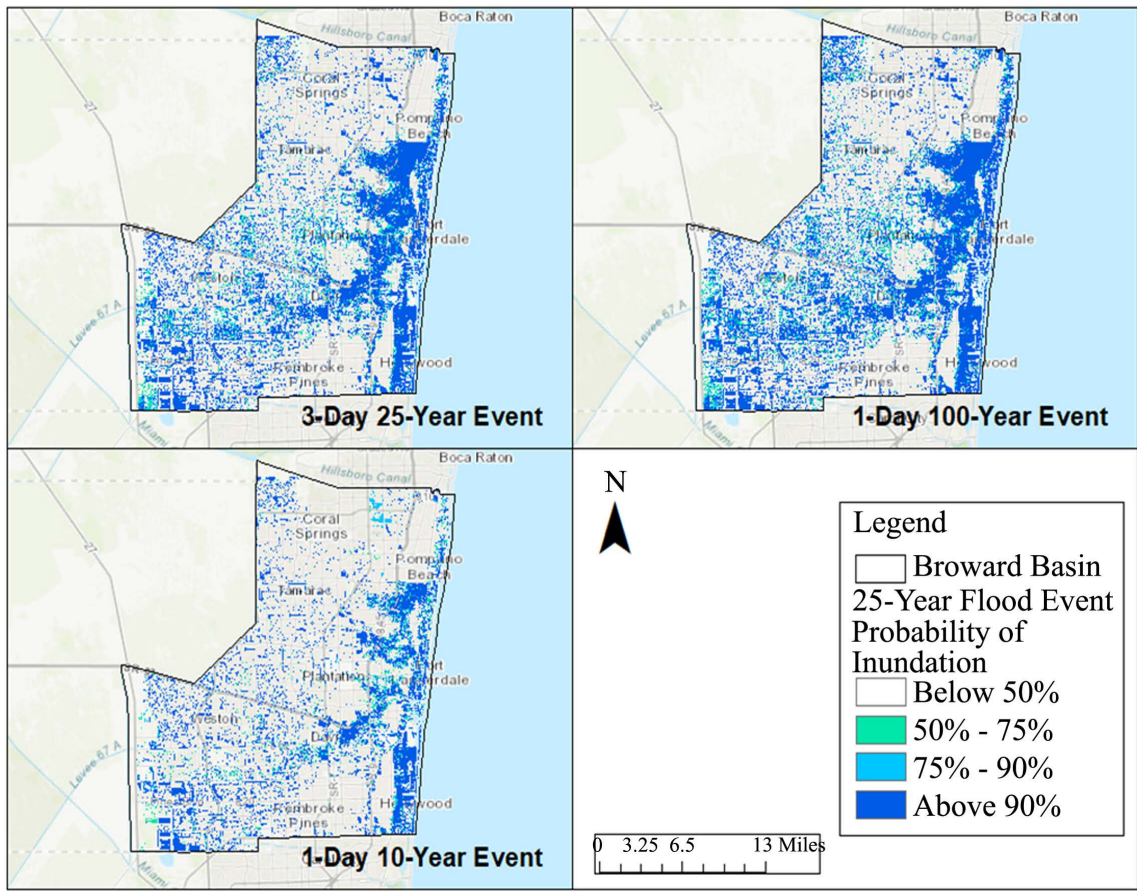

Figure 13. Flood inundations for 3-Day 25-Year, 1-Day 100-Year, and 1-Day 10-Year storm events-Broward county.

NFIP guidelines). Figure 14 shows the combination of these events. Figure 15 is the FEMA maps for the County. The methodology to analyze the areas was to query the FEMA map to find the A zone areas ( $\mathrm{AE}, \mathrm{AH}$, and $\mathrm{AO}$ ). $\mathrm{Z}_{-}$zones are not deemed to be flood prone. For the risk maps developed by the screening tool, the analysis was done with two different probability values, above $10 \%$ and 90\%. Table 2 shows the values for the A Zones from FEMA in Broward County. Comparing the FAU model and FEMA, Table 2 shows the overlap and acceptable agreement.

\section{Options for Correction}

Once the probability of flooding is determined, the next step is identify critical assets. To help with prioritization, the following is suggested:

- Tier 1 -Critical facility protection (water/sewer utilities, public safety, hospitals, schools, power).

- Tier 2-Essential facilities (groceries, pharmacies, roadways)

- Tier 3-Economic centers (protecting jobs)

- Tier 4-At risk communities

- Tier 5-Other urban/suburban property

- Tier 6-Agriculture/public property/vacant/undeveloped

Figure 16 shows the binary flood risk superimposed on the map of land uses, based on the DOR tiers from above. Based on their location, projects that maximize efforts to protect the critical assets can be imagined. 


\section{Broward Basin}

$5 \mathrm{ft}$ Sea Level Rise + 100-Year Flood Inundation

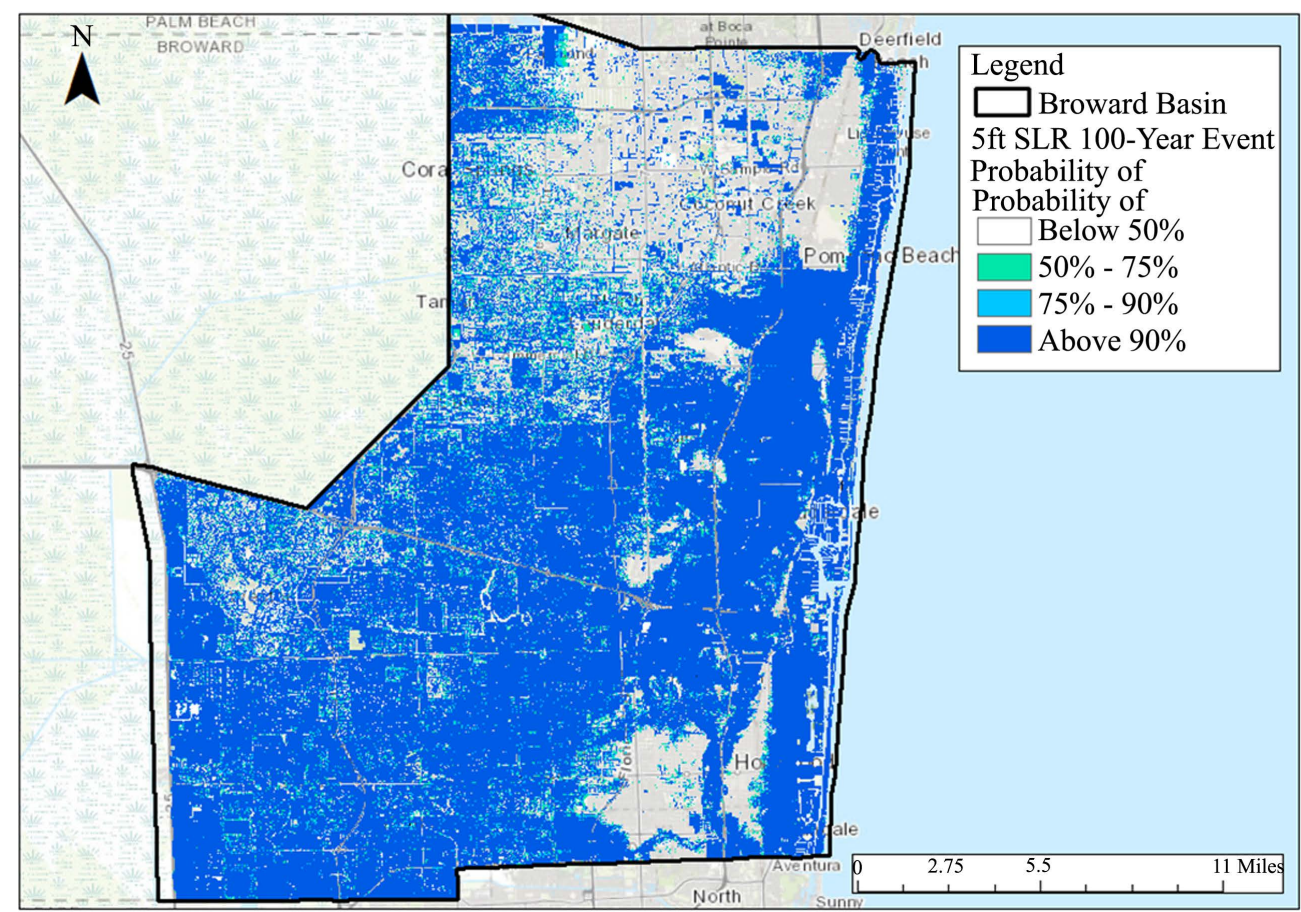

Figure 14. 5ft sea level rise + 1-Day 100-year flood inundation as requested to match NFIP guidelines-Broward county.

\section{Broward Basin}

Flood Insurance Risk Map (FIRM)

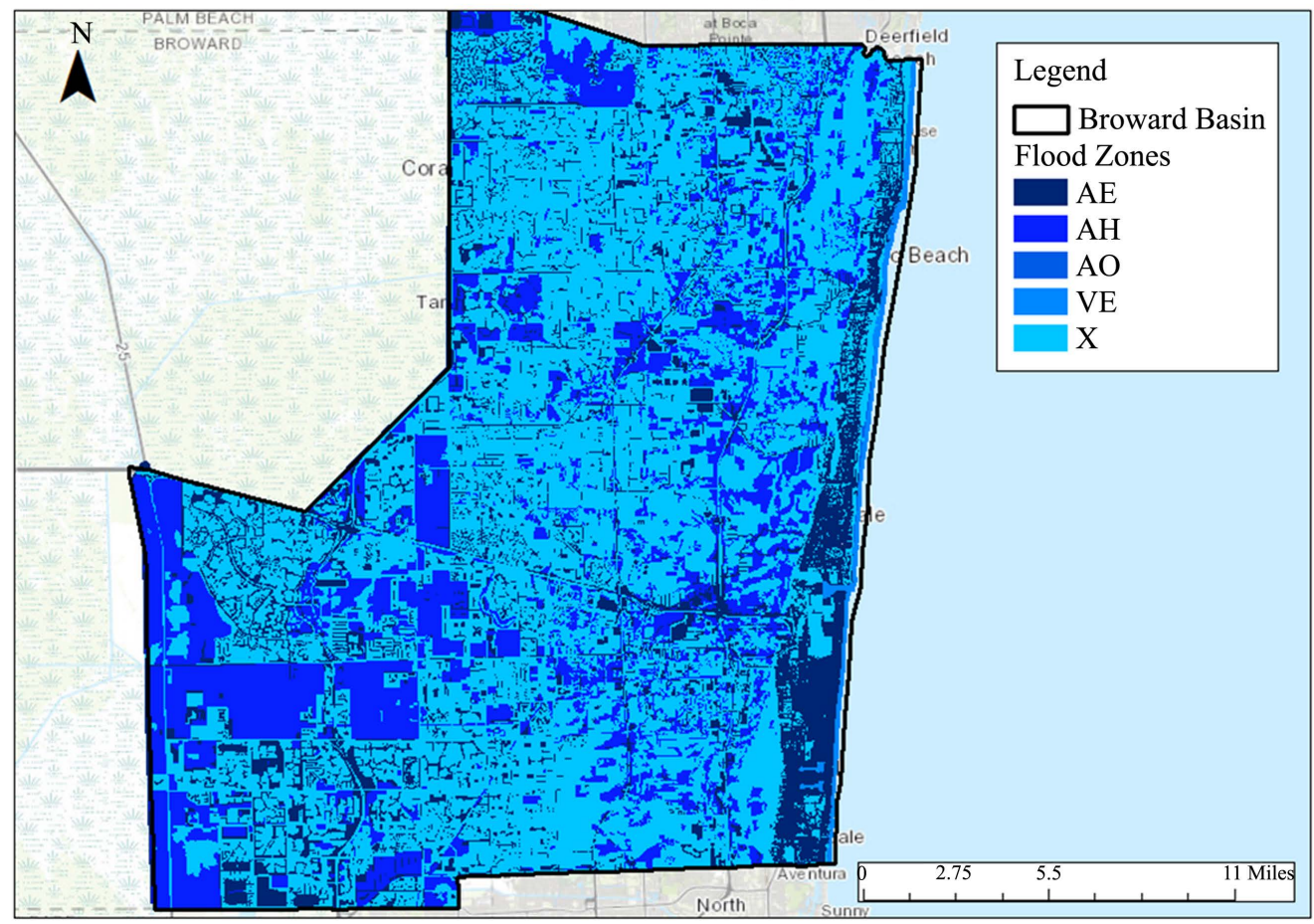

Figure 15. FEMA flood insurance risk map-Broward county. 


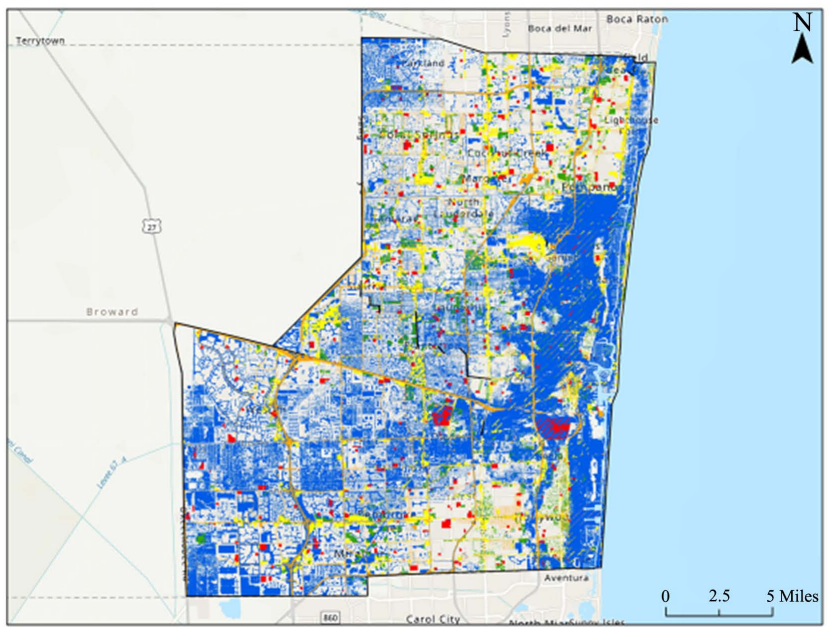

Flood Inundation \& Critical Facilities

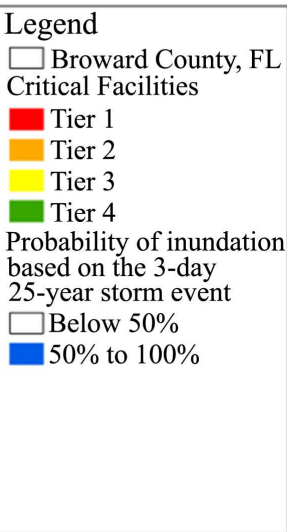

Figure 16. Broward County flood risk and locations of critical infrastructure.

Table 2. Comparison of FEMA vs.1-Day 100-Year screening tool flood risk map assessment-Broward county.

\begin{tabular}{cc}
\hline$\underline{\text { Description }}$ & Total Area $\left(\mathrm{mi}^{\wedge} 2\right)$ \\
\hline $\begin{array}{c}\text { FEMA's high-risk region based on the 100-year flood event } \\
(1 \% \text {-annual-chance Flood Hazard Areas) }\end{array}$ & 174.00 \\
FAU's high-risk region based on the 1-day 100-year storm event \\
(Above 90\% probability of inundation)
\end{tabular}

The process of identifying potential mitigation measures to implement begins with narrowing down the feasible engineering alternatives using threshold criteria and quantifiable selection criteria that include measures of effectiveness, cost, and added benefit to the community. The toolbox describes a variety of strategies that could be used to improve potential flood management conditions. They are community-specific and most require significant engineering and planning to determine the most efficient configuration to achieve the community's goals. Hard infrastructure systems are usually the first systems to be impacted because they are built at lower elevations than the finished floor of structures. In addition, many infrastructure systems are located within the roadways (water, sewer, stormwater, power, phone, cable tv, internet, etc.). At present, most roadway base courses are installed above the water table. If the base stays dry, the roadway surface will remain stable. As soon as the base is saturated, the roadway can deteriorate.

To help develop solutions for the identified priority areas, a toolbox was developed that describes a variety of strategies $(n=36)$ to improve potential flood management conditions. Table 3 outlines details for each of these "elements", including their benefits and limitations, which can be used by local officials to develop solutions to the areas identified by the model. This menu of green and grey infrastructure technologies is organized to address various flooding types, 
Table 3. Summary of benefits, costs, and barriers for each of the engineering alternatives in the toolbox.

\begin{tabular}{|c|c|c|c|c|c|}
\hline $\begin{array}{l}\text { Strategy } \\
\text { Class }\end{array}$ & $\begin{array}{l}\text { Implementation } \\
\text { Strategy }\end{array}$ & Applications & Benefits & Cost & Barriers to Implementation \\
\hline Green & $\begin{array}{l}\text { Bioretention } \\
\text { planter }\end{array}$ & $\begin{array}{l}\text { Local, small scale, } \\
\text { easily implemented } \\
\text { in developed areas }\end{array}$ & $\begin{array}{l}\text { Protects property, } \\
\text { treats runoff }\end{array}$ & $\$ 2500$ ea & $\begin{array}{c}\text { Limited volume disposed of, } \\
\text { so many are needed, } \\
\text { maintenance }\end{array}$ \\
\hline Green & Tree box filter & $\begin{array}{l}\text { Local, small scale, } \\
\text { easily implemented } \\
\text { in developed areas }\end{array}$ & $\begin{array}{l}\text { Protects property, } \\
\text { treats runoff }\end{array}$ & $\$ 2500$ ea & $\begin{array}{c}\text { Limited volume disposed of, } \\
\text { so many are needed, } \\
\text { maintenance }\end{array}$ \\
\hline Green & $\begin{array}{l}\text { Rainwater } \\
\text { harvesting }\end{array}$ & $\begin{array}{l}\text { Local, small scale, } \\
\text { easily implemented } \\
\text { in developed areas }\end{array}$ & $\begin{array}{l}\text { Protects property, } \\
\text { treats runoff }\end{array}$ & Under $\$ 5000$ & $\begin{array}{c}\text { Limited volume disposed of, } \\
\text { so many are needed, } \\
\text { maintenance }\end{array}$ \\
\hline Green & Vegetated roof & $\begin{array}{l}\text { Specific to a building, } \\
\text { absorbs water, } \\
\text { reduces runoff }\end{array}$ & $\begin{array}{l}\text { Protects property, } \\
\text { treats runoff }\end{array}$ & $\$ 100 /$ sf & $\begin{array}{l}\text { Requires irrigation if } \\
\text { insufficient rainfall occurs } \\
\text { Requires runoff control if } \\
\text { too much rainfall occurs }\end{array}$ \\
\hline Green & Bioswale & $\begin{array}{l}\text { Parking lots, runoff from } \\
\text { development-primarily } \\
\text { treatment for discharge to } \\
\text { another system }\end{array}$ & $\begin{array}{l}\text { Protects property, } \\
\text { treats runoff }\end{array}$ & $\$ 20 \mathrm{~K} / \mathrm{ac}$ & $\begin{array}{l}\text { Maintenance, limited } \\
\text { volume disposed of, used } \\
\text { mostly for treatment }\end{array}$ \\
\hline Gray & $\begin{array}{l}\text { Pervious } \\
\text { paving }\end{array}$ & $\begin{array}{l}\text { Parking lots, patios, } \\
\text { driveways, anything } \\
\text { except paved roads } \\
\text { due to traffic loading }\end{array}$ & $\begin{array}{l}\text { Reduces roadway } \\
\text { and parking } \\
\text { lot flooding }\end{array}$ & $\begin{array}{l}\$ 10-20 / s f, \\
\text { requires bumpers } \\
\text { and sub-base to } \\
\text { maintain paver } \\
\text { integrity }\end{array}$ & $\begin{array}{l}\text { Must be maintained via } \\
\text { vacuuming or the } \\
\text { perviousness fades } \\
\text { after } 2 \text { - } 3 \text { years }\end{array}$ \\
\hline Green & Detention & $\begin{array}{l}\text { Common for new } \\
\text { development, } \\
\text { but difficult to retrofit; } \\
\text { limited to open areas }\end{array}$ & $\begin{array}{l}\text { Removes water } \\
\text { from streets, } \\
\text { reduces flooding }\end{array}$ & $\$ 200 \mathrm{~K} / \mathrm{ac}$ & $\begin{array}{l}\text { Land availability, } \\
\text { maintenance of pond, } \\
\text { discharge location } \\
\text { Uses up land that could } \\
\text { otherwise be developed }\end{array}$ \\
\hline Green & Vegetated wall & $\begin{array}{l}\text { Used on walls of } \\
\text { buildings and } \\
\text { retaining walls }\end{array}$ & $\begin{array}{l}\text { Protects property, } \\
\text { treats runoff }\end{array}$ & $\$ 30 / s f$ & $\begin{array}{l}\text { Requires irrigation if } \\
\text { insufficient rainfall occurs } \\
\text { Requires runoff control if } \\
\text { too much rainfall occurs }\end{array}$ \\
\hline Gray & $\begin{array}{l}\text { Exfiltration } \\
\text { Trench }\end{array}$ & $\begin{array}{c}\text { Any low-lying area where } \\
\text { stormwater collects and the } \\
\text { water table is more than } 3 \mathrm{ft} \\
\text { below the surface; densely } \\
\text { developed areas } \\
\text { where retention is } \\
\text { not available, roadways }\end{array}$ & $\begin{array}{c}\text { Excess water } \\
\text { drains to aquifer, } \\
\text { some treatment } \\
\text { provided }\end{array}$ & $\$ 250 / \mathrm{ft}$ & $\begin{array}{l}\text { Significant damage to } \\
\text { roadways for installation, } \\
\text { maintenance needed, } \\
\text { clogging issues } \\
\text { reduce benefits }\end{array}$ \\
\hline Green & Dry Swale & $\begin{array}{l}\text { Parking lots, runoff from } \\
\text { development-primarily } \\
\text { treatment for discharge } \\
\text { to another system }\end{array}$ & $\begin{array}{l}\text { Protects Property, } \\
\text { treats runoff }\end{array}$ & $\$ 200 \mathrm{~K} / \mathrm{mi}$ & $\begin{array}{l}\text { Maintenance, limited } \\
\text { volume disposed of, } \\
\text { mostly for treatment }\end{array}$ \\
\hline Green & Retention Ponds & $\begin{array}{l}\text { Common for new } \\
\text { development, but difficult } \\
\text { to retrofit; } \\
\text { limited to open areas }\end{array}$ & $\begin{array}{l}\text { Removes water from } \\
\text { streets, reduces } \\
\text { flooding }\end{array}$ & $\$ 200 \mathrm{~K} / \mathrm{ac}$ & $\begin{array}{l}\text { Land availability, } \\
\text { maintenance of pond, } \\
\text { discharge location } \\
\text { Uses up land that could } \\
\text { otherwise be developed }\end{array}$ \\
\hline
\end{tabular}




\section{Continued}

\begin{tabular}{|c|c|c|c|c|c|}
\hline Green & Rain Gardens & $\begin{array}{l}\text { Local, small scale, } \\
\text { easily implemented in } \\
\text { developed areas }\end{array}$ & $\begin{array}{l}\text { Protects property, } \\
\text { treats runoff }\end{array}$ & $\$ 20 \mathrm{~K} / \mathrm{ac}$ & $\begin{array}{l}\text { Limited volume disposed of, } \\
\text { so many are needed, } \\
\text { maintenance }\end{array}$ \\
\hline Gray & Infiltration Trench & $\begin{array}{l}\text { Low lying areas that collect } \\
\text { stormwater, but the water } \\
\text { table is just below the surface } \\
\text { meaning that retention and } \\
\text { exfiltration trenches } \\
\text { will not work properly }\end{array}$ & $\begin{array}{l}\text { Excess water is } \\
\text { drained to pump } \\
\text { stations, creating } \\
\text { soil storage capacity } \\
\text { to store runoff, } \\
\text { soil treatment }\end{array}$ & $\begin{array}{l}\$ 250 / \mathrm{ft} \text { plus } \\
\text { pump station }\end{array}$ & $\begin{array}{l}\text { Significant damage to } \\
\text { roadways for installation, } \\
\text { maintenance needed, } \\
\text { clogging issues-must } \\
\text { discharge somewhere (pump } \\
\text { station, detention pond) }\end{array}$ \\
\hline Green & Oversized pipes & $\begin{array}{l}\text { Local solution-not } \\
\text { watershed level, holds } \\
\text { water to reduce flooding }\end{array}$ & $\begin{array}{l}\text { Protects property } \\
\text { and roadways }\end{array}$ & $\begin{array}{l}\$ 350 / \mathrm{ft} \\
\text { of more }\end{array}$ & $\begin{array}{l}\text { Sediments, maintenance } \\
\text { needs, lack of means } \\
\text { to flush, cost }\end{array}$ \\
\hline Gray & $\begin{array}{l}\text { Central sewer } \\
\text { installation }\end{array}$ & $\begin{array}{c}\text { All areas where there } \\
\text { are septic tanks. } \\
\text { Mostly a water quality issue }\end{array}$ & $\begin{array}{l}\text { Public health benefit } \\
\text { of reducing } \\
\text { discharges to lawns, } \\
\text { canals and } \\
\text { groundwater from } \\
\text { septic tanks }\end{array}$ & $\begin{array}{l}\$ 15,000 \text { per } \\
\text { household }\end{array}$ & $\begin{array}{l}\text { Cost, assessments } \\
\text { against property owners, } \\
\text { property rights issues }\end{array}$ \\
\hline Green & Filter strips & Localized & $\begin{array}{l}\text { Protects property, } \\
\text { treats runoff }\end{array}$ & $\$ 50 \mathrm{~K} / \mathrm{mi}$ & $\begin{array}{l}\text { Does not address flooding, } \\
\text { treatment/water } \\
\text { quality measure }\end{array}$ \\
\hline Green & $\begin{array}{c}\text { Flood prone } \\
\text { property acquisition }\end{array}$ & $\begin{array}{l}\text { Regional agency-could } \\
\text { be any low-lying areas }\end{array}$ & $\begin{array}{l}\text { Removes flood } \\
\text { prone areas from risk }\end{array}$ & $\begin{array}{l}\$ 2 \mathrm{~K}-\$ 100 \mathrm{~K} / \mathrm{ac} \\
\text { depending on } \\
\text { whether it is } \\
\text { already developed }\end{array}$ & $\begin{array}{l}\text { Difficult to implement if } \\
\text { occupied, issues with willing } \\
\text { sellers, cost, lack of funds } \\
\text { for acquisition }\end{array}$ \\
\hline Gray & Class I injection wells & $\begin{array}{l}\text { Any low-lying area where } \\
\text { stormwater collects, and there } \\
\text { is sufficient land to permit, } \\
\text { install and operate a } \\
\text { Class I well-limited }\end{array}$ & $\begin{array}{l}\text { Means to drain } \\
\text { neighborhoods- } \\
\text { potentially } \\
\text { arge volumes }\end{array}$ & $\begin{array}{l}\text { \$3-6 million } \\
\text { depending on } \\
\text { size/depth }\end{array}$ & $\begin{array}{l}\text { Needs baffle box, injection } \\
\text { zone may not be available, } \\
\text { requires a permit, may } \\
\text { compete with water users }\end{array}$ \\
\hline Green & Underground storage & $\begin{array}{l}\text { Common for new } \\
\text { developments, but } \\
\text { difficult to retrofit }\end{array}$ & $\begin{array}{l}\text { Storage of excess } \\
\text { runoff from rainfall, } \\
\text { can be used for } \\
\text { irrigation, can sit } \\
\text { under parking lots, } \\
\text { unobtrusive }\end{array}$ & $\$ 2 / \mathrm{gal}$ & $\begin{array}{l}\text { If the tank is full, } \\
\text { there is no storage }\end{array}$ \\
\hline Green & Constructed wetlands & $\begin{array}{l}\text { Where there is low lying } \\
\text { flood prone land that can be } \\
\text { converted into wetlands }\end{array}$ & $\begin{array}{l}\text { Reduces flooding by } \\
\text { providing a low-lying } \\
\text { area for water to go }\end{array}$ & $\$ 200-\$ 1 \mathrm{M} / \mathrm{ac}$ & $\begin{array}{l}\text { Water quality, permitting, } \\
\text { monitoring costs, } \\
\text { maintenance }\end{array}$ \\
\hline Gray & Pump stations & $\begin{array}{l}\text { Any low-lying area where } \\
\text { stormwater collects, and } \\
\text { there is a place to pump } \\
\text { the excess stormwater } \\
\text { to such as a canal; } \\
\text { common for developed areas }\end{array}$ & $\begin{array}{l}\text { Removes water } \\
\text { from streets, } \\
\text { reduces flooding }\end{array}$ & $\begin{array}{l}\text { Start at } \$ 1.5 \text { to } 5 \\
\text { million each, } \\
\text { number unclear } \\
\text { without } \\
\text { more study }\end{array}$ & $\begin{array}{l}\text { NPDES permits, } \\
\text { maintenance cost, } \\
\text { land acquisition, } \\
\text { discharge quality }\end{array}$ \\
\hline Gray & $\begin{array}{c}\text { Armored } \\
\text { sewer systems }\end{array}$ & $\begin{array}{l}\text { Any area where gravity } \\
\text { sanitary sewers are installed }\end{array}$ & $\begin{array}{l}\text { Keeps stormwater } \\
\text { out of sanitary sewer } \\
\text { system and reduces } \\
\text { potential for disease } \\
\text { spread from sewage } \\
\text { overflows }\end{array}$ & $\$ 500 /$ manhole & $\begin{array}{c}\text { Limited expense } \\
\text { beyond capital cost }\end{array}$ \\
\hline
\end{tabular}




\section{Continued}

\begin{tabular}{|c|c|c|c|c|c|}
\hline Gray & Raised roadways & $\begin{array}{l}\text { Limited to areas where } \\
\text { redevelopment is occurring } \\
\text { areawide due to ancillary } \\
\text { impacts on adjacent properties }\end{array}$ & $\begin{array}{l}\text { Keeps traffic above } \\
\text { floodwaters, access } \\
\text { for emergency } \\
\text { vehicles, commerce }\end{array}$ & $\begin{array}{c}\quad \$ 2-4 \\
\text { million/lane mile }\end{array}$ & $\begin{array}{l}\text { Runoff, cost, } \\
\text { utility relocation }\end{array}$ \\
\hline Gray & $\begin{array}{l}\text { Class } \mathrm{V} \\
\text { gravity wells }\end{array}$ & $\begin{array}{l}\text { Any low-lying areas where } \\
\text { stormwater collects and is } \\
\text { located where saltwater has } \\
\text { intruded the surficial } \\
\text { aquifer beneath the site }\end{array}$ & $\begin{array}{l}\text { Means to drain } \\
\text { neighborhoods, } \\
\text { limited volume }\end{array}$ & $\$ 250 \mathrm{~K}$ each & $\begin{array}{l}\text { Needs baffle box, limited flow } \\
\text { volume (1 MGD), zone for } \\
\text { discharge may not be available, } \\
\text { permits, water supply wells }\end{array}$ \\
\hline Gray & Canals & Limited & $\begin{array}{l}\text { Means to drain } \\
\text { neighborhoods, } \\
\text { provides treatment } \\
\text { of water }\end{array}$ & $\$ 2$ million/mile & $\begin{array}{l}\text { Land area, flow volume, } \\
\text { maintenance, ownership, } \\
\text { capacity issues due to } \\
\text { sea level rise pressure }\end{array}$ \\
\hline Green & Aquatic zones & $\begin{array}{l}\text { Any low-lying or } \\
\text { flood-prone area that is } \\
\text { undeveloped and can } \\
\text { store large volumes of water }\end{array}$ & $\begin{array}{l}\text { Place to store large } \\
\text { volumes of water }\end{array}$ & $\$ 200 \mathrm{~K} / \mathrm{ac}$ & $\begin{array}{l}\text { Must be maintained, cost, } \\
\text { impact on property owners }\end{array}$ \\
\hline Gray & Levees & $\begin{array}{l}\text { Regional issue-along rivers, } \\
\text { lakes, impoundments }\end{array}$ & $\begin{array}{c}\text { Protects } \\
\text { widescale property }\end{array}$ & \$ millions & $\begin{array}{l}\text { Must be maintained, must be } \\
\text { continuous, must be planned } \\
\text { for extreme events (i.e. } \\
\text { Hurricane Katrina showed } \\
\text { that New Orleans planning } \\
\text { horizon was not sufficient) }\end{array}$ \\
\hline Gray & Lock structures & $\begin{array}{l}\text { Regional (WMD) } \\
\text { responsibility }\end{array}$ & $\begin{array}{l}\text { Keeps seawater out, } \\
\text { reduces saltwater } \\
\text { intrusion }\end{array}$ & $\begin{array}{l}\text { Up to } \$ 10 \text { million, } \\
\text { may require } \\
\text { ancillary } \\
\text { stormwater } \\
\text { pumping stations } \\
\text { at } \$ 2-5 \text { million } \\
\text { each }\end{array}$ & $\begin{array}{l}\text { Permitting, private } \\
\text { property rights } \\
\text { arguments }\end{array}$ \\
\hline Gray & Sea walls & $\begin{array}{c}\text { Barrier islands and } \\
\text { downtown coastal areas }\end{array}$ & Protects property & $\$ 1200 / \mathrm{ft}$ & $\begin{array}{c}\text { Private property rights, } \\
\text { neighbors }\end{array}$ \\
\hline Green & Polders & $\begin{array}{c}\text { Barrier islands and } \\
\text { downtown coastal areas }\end{array}$ & $\begin{array}{l}\text { Provides storage } \\
\text { for coastal waters }\end{array}$ & $\$ 200 \mathrm{~K} / \mathrm{ac}$ & Permitting, land acquisition \\
\hline Gray & Surge barriers & $\begin{array}{c}\text { Coastal communities-large } \\
\text { footprint }\end{array}$ & Protects property & $>\$ 1 \mathrm{~B}$ & $\begin{array}{l}\text { Cost, open ocean access } \\
\text { challenges, property rights }\end{array}$ \\
\hline Green & $\begin{array}{l}\text { Enhanced } \\
\text { wetlands }\end{array}$ & $\begin{array}{l}\text { Where there is an existing } \\
\text { wetlands area that } \\
\text { can be augmented }\end{array}$ & $\begin{array}{l}\text { Reduces flooding by } \\
\text { providing a low-lying } \\
\text { place for water to go }\end{array}$ & $\$ 200-\$ 1 \mathrm{M} / \mathrm{ac}$ & $\begin{array}{c}\text { Water quality, permitting, } \\
\text { monitoring costs, maintenance, } \\
\text { ecosystem impacts }\end{array}$ \\
\hline Green & Revetments & $\begin{array}{l}\text { Retention, helps maintain the } \\
\text { storage volume, in conjunction } \\
\text { with other measures }\end{array}$ & $\begin{array}{l}\text { Improves walls of } \\
\text { retainage }\end{array}$ & $\begin{array}{l}\text { Varies based on } \\
\text { material, depth, } \\
\text { wall height }\end{array}$ & Land area, maintenance \\
\hline Policy & Changes in land use & Applicable universally & $\begin{array}{l}\text { Achieves flood risk } \\
\text { mitigation by } \\
\text { djusting permitted } \\
\text { land use }\end{array}$ & $\begin{array}{l}\text { Low but may } \\
\text { incur private } \\
\text { property rights } \\
\text { conflicts and } \\
\text { litigation }\end{array}$ & $\begin{array}{l}\text { Private property } \\
\text { rights conflicts } \\
\text { and litigation }\end{array}$ \\
\hline Gray & $\begin{array}{c}\text { Roadway } \\
\text { base protection }\end{array}$ & $\begin{array}{l}\text { Low-lying areas, coastal } \\
\text { communities }\end{array}$ & $\begin{array}{l}\text { Protects roads and } \\
\text { access routes }\end{array}$ & $\begin{array}{l}\$ 1 \text { million } \\
\text { per lane mile }\end{array}$ & $\begin{array}{l}\text { Cost, adjacent properties } \\
\text { become uninsurable }\end{array}$ \\
\hline Policy & $\begin{array}{l}\text { Enhanced elevation } \\
\text { of buildings or } \\
\text { land abandonment }\end{array}$ & $\begin{array}{l}\text { Developers would } \\
\text { implement this } \\
\text { for new construction }\end{array}$ & Reduced flood risk & Varies & $\begin{array}{l}\text { Potential issues with building } \\
\text { structure or latticework, } \\
\text { and existing homes } \\
\text { that are not elevated }\end{array}$ \\
\hline
\end{tabular}


from pluvial (rainfall and runoff mitigation in upland areas), fluvial (runoff, high ground water, and surface water management in low-lying flood prone areas), tidal (flooding associated with storm surge, high ground water, and tidally influenced), and all (applies across the spectrum). Each is site-specific, and most require significant engineering and planning to determine the most efficient configuration to achieve the community's goals.

\section{Conclusion}

Flood risk analysis is the instrument by which floodplain and stormwater utility managers create a sound strategy and adaptation plans to reduce flood potential in their communities. The goal of this study was to demonstrate a screening tool to identify areas at higher risk of flooding by implementing a water surface derived from groundwater levels, surface gage heights, and tidal influences to create a map of minimum soil storage capacity. The screening tool applies various rainfall events to this initial condition to determine the risk of flooding for each scenario. The study showed that the groundwater influence model, which is not contemplated under current modeling methods by government agencies or other parties, is capable of identifying higher risk areas on a subwatershed scale. This is important because communities creating watershed master plans will be empowered and find solutions to four of the seven CRS requirements, if the screening tool is implemented:

1) Evaluate the watershed's runoff response from design storms of various magnitudes and durations under current and predicted future conditions.

2) Assess the impacts of sea-level rise and climate change.

3) Implement regulatory standards for new development such that peak flows and volumes are under control.

4) Include specific mitigation recommendations to ensure that communities are resilient in the future.

The objective of evaluating areas at the subwatershed scale was achieved, with overlap of over $50 \%$ when compared to FEMA FIRMs, realizing the FIRM maps and model do not scan for the same issues. As a result, the framework for the screening tool accurately identifies risk areas to assist decision-makers in developing appropriate mitigation strategies. Thus the screening tool will help officials create plans that are fundamental to providing necessary levels of drainage and flood protection under future climate conditions and development scenarios.

The strengths of this framework are the initial focus on location-specific science, enabling policy makers to develop long-term decisions with respect to infrastructure investments, because infrastructure and development are not temporal-they are expected to last 50 years or more. Hence it is in a community's interest to develop a planning framework to adapt to flooding conditions to protect vulnerable infrastructure through a long-term plan. Because vulnerability can never be estimated with 100 percent accuracy, the conventional anticipa- 
tion approach should be replaced or supplemented with one that recognizes the importance of building resiliency.

Further study should focus on four areas:

1) Application to a less flat, rocky terrain to determine if the protocols can be transferred outside Florida.

2) Rainfall was assumed to be consistent across the watershed. This rarely happens. A heuristic model of rainfall could better represent actual conditions.

3) A predictive model could be developed to evaluate prior events as a tool for predicting future results.

\section{Conflicts of Interest}

The authors declare no conflicts of interest regarding the publication of this paper.

\section{References}

Arundel, A., Casali, L., \& Hollanders, H. (2015). How European Public Sector Agencies Innovate: The Use of Bottom-Up, Policy-Dependent and Knowledge-Scanning Innovation Methods. Research Policy, 44, 1271-1282.

https://doi.org/10.1016/j.respol.2015.04.007

Bloetscher, F. (2012). Protecting People, Infrastructure, Economies, and Ecosystem Assets: Water Management and Adaptation in the Face of Climate Change. Water, 4, 367-388. https://doi.org/10.3390/w4020367

Bloetscher, F., \& Romah, T. (2015). Tools for Assessing Sea Level Rise Vulnerability. Journal of Water and Climate Change, 6, 181-190. https://doi.org/10.2166/wcc.2014.045

Bloetscher, F., \& Wood, M. (2016). Assessing the Impacts of Sea Level Rise Using Existing Data. Journal of Geoscience and Environment Protection, 4, 159-183. https://doi.org/10.4236/gep.2016.49012

Bloetscher, F., Abbate, A., Huber, J., Liu, W., Meeroff, D. E., Mitsova, D., Nagarajan, S., Polsky, C., Su, H., Teegavarapu, R., Xie, Z., Yong, Y., Zhang, C., Hindle, T., Hoque, M., Jones, R., Oglesby, G., Suarez, E., \& Weaver, J. (2021). Establishing a Framework of a Watershed Wide Screening Tool to Support Development of Watershed Based Flood Protection Plans in Low-Lying Coastal Communities. Journal of Infrastructure, Policy and Development, 5, 1273. https://doi.org/10.24294/jipd.v5i1.1273

Carlton, D. (2021). NFIP Reviewer, Personnel Communication 4/15/21.

Chang, S. W., Clement, T. P., Simpson, M. J., \& Lee, K. (2011). Does Sea-Level Rise Have an Impact on Salt Water Intrusion? Advances in Water Resources, 34, 1283-1291. https://doi.org/10.1016/j.advwatres.2011.06.006

E Sciences (2014). Groundwater Elevation Monitoring and Mapping Six Monitoring Stations throughout Miami Beach, Miami Beach, Miami-Dade County, Florida. E Sciences Project Number 7-0002-005, Fort Lauderdale.

FEMA (2016). FEMA Elevation Guidance (Document 47). https://www.fema.gov/sites/default/files/2020-02/Elevation_Guidance_May_2016.pdf

FEMA (2017). Community Rating System Fact Sheet. https://www.fbfl.us/DocumentCenter/View/17848/NFIP_CRS_Fact_Sheet_2017_508O K?bidId

FEMA (Federal Emergency Management Agency) (2003). Map Modernization, Guide- 
lines, and Specifications for Flood Hazard Mapping Partners; Appendix A: Guidance for Aerial Mapping and Surveying (57 p.). Federal Emergency Management Agency.

FLUCCS-SFWMD (2012). https://www.mapwise.com/maps/florida/land-cover.php

Heidemann, H. K. (2014). Lidar Base Specification (Version 1.2, November 2014): U.S. Geological Survey Techniques and Methods (Book 11, Chap. B4, 67 p. with Appendixes). https://doi.org/10.1017/CBO9780511546013

Jin, S., Homer, C. G., Yang, L., Danielson, P., Dewitz, J., Li, C., Zhu, Z., Xian, G., \& Howard, D. (2019). Overall Methodology Design for the United States National Land Cover Database 2016 Products. Remote Sensing, 11, 2971. https://doi.org/10.3390/rs11242971

Moftakhari, H. R., AghaKouchak, A., Sanders, B. F., \& Matthew, R. A. (2017). Cumulative Hazard: The Case of Nuisance Flooding. Earths Future, 5, 214-223. https://doi.org/10.1002/2016EF000494

National Oceanic and Atmospheric Administration (NOAA) (2010). Mapping Inundation Uncertainty. NOAA Coastal Services Center. https://www.esrl.noaa.gov/research/reviews/2010/posters/4-12-Cox.pdf

Romah, T. (2011). Advanced Methods in Sea Level Rise Vulnerability Assessment. Master Thesis, Florida Atlantic University.

Rotzoll, K., \& Fletcher, C. H. (2013). Assessment of Groundwater Inundation as a Consequence of Sea-Level Rise. Nature Climate Change, 3, 477-481. https://doi.org/10.1038/nclimate1725

Schmid, K., Hadley, B., \& Waters, K. (2014). Mapping and Portraying Inundation Uncertainty of Bathtub-Type Models. Journal of Coastal Research, 30, 548-561. https://doi.org/10.2112/JCOASTRES-D-13-00118.1

Serafin, K. A., \& Ruggiero, P. (2014). Simulating Extreme Total Water Levels Using a Time-Dependent, Extreme Value Approach. Journal of Geophysical Research: Oceans, 119, 6305-6329. https://doi.org/10.1002/2014JC010093

Soil Survey Staff (2020). The Gridded Soil Survey Geographic (gSSURGO) Database for Florida. United States Department of Agriculture, Natural Resources Conservation Service. https://gdg.sc.egov.usda.gov

South Florida Water Management District (SFWMD) (2001). Technical Publication REG-003: User's Guide for the Routing Model Cascade 2001.

Stockdon, H. F., Holman, R. A., Howd, P. A., \& Sallenger Jr., A. H. (2006). Empirical Parameterization of Setup, Swash, and Runup. Coastal Engineering, 53, 573-588. https://doi.org/10.1016/j.coastaleng.2005.12.005

Sukop, M. C., Rogers, M., Guannel, G., Infanti, J. M., \& Hagemann, K. (2018). High Temporal Resolution Modeling of the Impact of Rain, Tides, and Sea Level Rise on Water Table Flooding in the Arch Creek Basin, Miami-Dade County Florida USA. Science of the Total Environment, 616, 1668-1688.

https://doi.org/10.1016/j.scitotenv.2017.10.170

Sweet, W., Marra, J., \& Dusek, G. (2017). 2016 State of U.S. High Tide Flooding and a 2017 Outlook [Supplement to State of the Climate: National Overview for May 2017]. https://www.ncdc.noaa.gov/monitoring-content/sotc/national/2017/may/2016_Stateof HighTideFlooding.pdf

Wahl, T., Jain, S., Bender, J., Meyers, S. D., \& Luther, M. E. (2015). Increasing Risk of Compound Flooding from Storm Surge and Rainfall for Major US Cities. Nature Climate Change, 5, 1093-1097. https://doi.org/10.1038/nclimate2736

Wood, M. (2016). Using a Groundwater Influenced Sea Level Rise Model to Assess the 
Costs Due to Sea-Level Rise on a Coastal Community's Stormwater Infrastructure Using Limited Groundwater Data. Master Thesis, Florida Atlantic University.

Zhang, C., Su, H., Li, T., Liu, W., Mitsova, D., Nagarajan, S., Teegavarapu, R., Xie, Z., Bloetscher, F., \& Yong, Y. (2020). Modeling and Mapping High Water Table for a Coastal Region in Florida Using Lidar DEM Data. Groundwater, 59, 190-198.

https://doi.org/10.1111/gwat.13041 